\title{
A Doctor in the House: The Architecture of Home-offices for Physicians in Toronto, $1885-1930$
}

\author{
ANNMARIE ADAMS and STACIE BURKE*
}

\begin{abstract}
Introduction
Dr William Dumble's house in Toronto (Figure 1) looked like many other middle-class homes constructed in North American urban centres in the early twentieth century. ${ }^{1}$ The twostorey, brick house with a hipped roof and dormer window was typical in its blocky massing, pronounced chimney, generous setback from the street, contrasting materials, and careful detailing. Such houses were intended to house a typical family: two parents, perhaps a few children, and maybe a servant or lodger. Even the way the architects Burke, Horwood and White drew the building's façade - in soft pencil and red ink on tracing paper, showing the warm tone of the red brick and the rough texture of the stucco trim and manicured lawn-signalled domesticity. Both the house design and the architect's drawing, that is, were styled to appear friendly, inviting, and traditional. The house corresponds to the general type of domestic architecture built in the late nineteenth and early twentieth centuries, a picturesque, non-classical, asymmetrical cottage "with diverse visual and tactile effects on the exterior and an integration between exterior form and inside spaces". 2

Burke, Horwood and White's floor plan of the house, however, reveals little integration between the front elevation and the spaces inside, which were much more commercial and scientific than the homey exterior suggested. Behind the bay window, to the right of the front door, was the physician's office; across the hall, boasting white pine trim, oak borders, and a gas fireplace, was a waiting-room for patients. Indeed, nearly half of the ground floor area of the Dumble house was given over to his medical practice, with a close and direct connection to rooms presumably used by his family and live-in
\end{abstract}

(C) Annmarie Adams and Stacie Burke 2008

*Annmarie Adams, PhD, William C Macdonald Professor, School of Architecture, McGill University; Stacie Burke, PhD, Assistant Professor, Department of Anthropology, University of Manitoba. Address for correspondence: Professor Annmarie Adams, School of Architecture, McGill University, 815 Sherbrooke St West, Montreal, Quebec, Canada H3A 2K6; e-mail: annmarie.adams@mcgill.ca

We would like to thank the journal's anonymous reviewers, Jennifer Connor, Jim Connor, Raphaël Fischler, Marta Gutman, Charlotte Humphrey, Sherry Olson, Kevin Schwartzman, and David Theodore. We are also especially grateful to research assistants
Megan Highet and Natalie Ludlow, who undertook the search for Toronto doctors in the 1901 census, and Richard Maaranen, who designed the maps.

\footnotetext{
${ }^{1}$ Born in Cobourg, Ontario, in 1848, Dumble matriculated from the University of Queen's College, Kingston, Faculty of Medicine, in 1870 and practised in Owen Sound, Ontario, and New York City before his death in Toronto on 21 Nov. 1928 aged eighty-one. William Charles Dumble, Register of Students, Volume 1, n 1-796, coll. 1161, Queen's University Archives.

${ }^{2}$ Jan Jennings, Cheap and tasteful dwellings: design competitions and the convenient interior, 1879-1909, Knoxville, University of Tennessee Press, 2005, p. 120.
} 


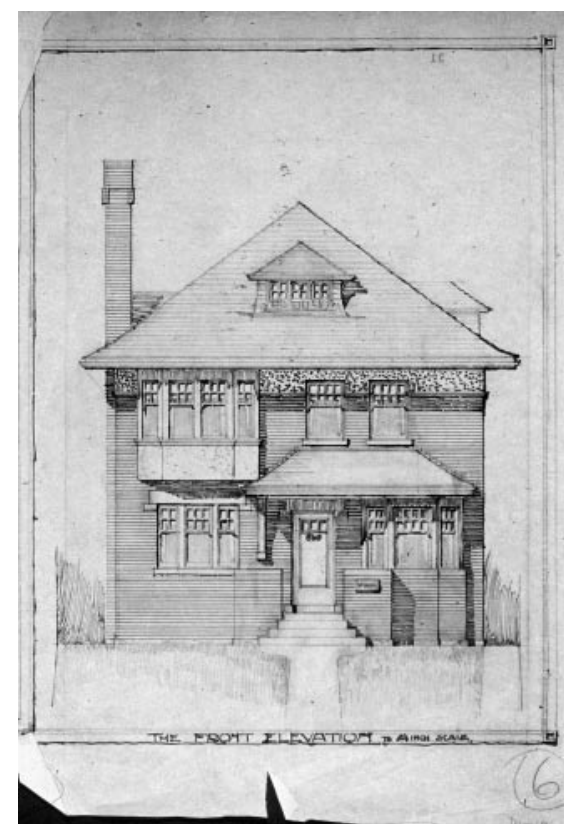

Figure 1: Burke, Horwood and White's sketch for the house-office of Dr William C Dumble, Toronto, 1909. Archives of Ontario, C 11-325, (1030) 31.

servant(s): the dining-room, stairway, and kitchen. A number of initial questions flow from the Dumble house example and frame our general interests in this combination of family and work: which physicians invested in home practices and why? How did the home-office function? What was its relationship to the traditional family home?

This interdisciplinary paper explores the design and distribution of home-offices or house-offices ${ }^{3}$ in Toronto, Ontario, using data gathered from city directories, nominal census returns, architectural drawings, photographs, obituaries, and death notices. Our approach combines interests in architectural analysis and the historic role of physicians in the design of everyday medical space with a demographic and social perspective on the nature and distribution of specialized households in an urban context. ${ }^{4}$ The approach is cross-sectional, with a direct and comprehensive examination of physicians practising in 1901 Toronto, which, at that time, was Canada's second largest city with a population of almost 240,000. ${ }^{5}$ The genesis of this work was the discovery of a selection of architects' drawings for home-offices, including Dr Dumble's, in the Archives of Ontario.

\footnotetext{
${ }^{3}$ In British English the house-office is more accurately the "surgery" or "consulting room".

${ }^{4}$ For a survey of other contemporary approaches to medical history, see Peter L Twohig, 'Recent writing on health care history in Canada', Scientia Canadensis, 2002, 26: 7-28.
}

\footnotetext{
${ }^{5}$ For a similar geographical inquiry, see J E Turnbridge, 'Separation of residence from workplace: a Kingston example', Urban Hist. Rev., 1978, 3: 23-32; Jennifer J Connor and Jean Harris touch on the overlap of doctors' private and professional lives in, 'Estate Records of Health Practitioners in Ontario, 1793-1900', Can. Bull.med. Hist., 1993, 10: 115-43.
} 


\section{The Architecture of Home-offices for Physicians in Toronto, 1885-1930}

The paper is structured around three main sub-arguments. The first challenges the common perception that urban physicians practised medicine in more sharply-defined and formalized spaces than their rural counterparts. ${ }^{6}$ Of the 342 physicians advertising their practice through listings in Might's Toronto City Directory in 1901, 311 or 91 per cent maintained a house-office. As there were a number of other physicians practising in Toronto at this time who did not advertise in the directory, our study focuses only on those actively promoting their independent practices.

Interior photographs of the offices of Francis Buller, an oculist, and Herbert Stanley Birkett, a laryngologist, in 1890 Montreal reveal the ambiguous and informal feel of the urban physician's home-office (Figure 2). The presence of the safe, interior finishes and general ambience in photographs of Buller and Birkett's premises, for example, provide material evidence of the profitability of urban medicine at this time. The conspicuous display of books (symbolizing medical knowledge), medical instruments, fine furniture, and carpets, are signs of prestige, alluding to the physicians' credentials and status. These domestic trappings were a significant aspect of what the medical historian Edward Shorter has defined as the "modern" doctor-patient relationship in the pre-Second World War period, framed by "traditional" and "postmodern" periods. According to Shorter, the physician's authority rested on the appearance (his emphasis) of caring, expressed in actions such as the laying on of hands, counselling patients in intimate problems, and privileging personal history. ${ }^{7}$ The domestic setting contributed to this image of the doctor as an understanding confidant, almost like a member of the family, while the conspicuously expensive touches reinforced the cultural and material choices of fee-paying patients. As George Bernard Shaw said in his preface to the 1911 The doctor' s dilemma, "[Doctors] must believe, on the whole, what their patients believe, just as they must wear the sort of hat their patients wear". ${ }^{8}$ Like Shaw's hat, the home-based office, in its subtle overlap with the family home, subconsciously linked patients and their physicians. The floor plans of home-offices, too, show how glimpses of the doctor's family life may have boosted his or her professional roles.

This model of the physician home-office emerged from larger structural and technological changes that were occurring in Canada (and, more broadly, North America) at the time. The standard medical model of practice had traditionally been associated with physicians attending patients in their own homes, in a home-visiting model of practice. As Neil Larry Shumsky, James Bohland, and Paul Knox have argued, "the lack of urban transportation meant that the basic setting for health care was the patient's bedside rather

\footnotetext{
${ }^{6}$ For rural examples, see the Colby house in Stanstead, Quebec; the Hillary House Koffler Museum of Medicine in Aurora, Ontario; the Hutchison House Museum in Peterborough, Ontario; the Banting House in London, Ontario; and the Shipman house in Glendale, California. See Lewis Thomas' autobiographical essays in The youngest science: notes of a medicine-watcher, New York, Oxford University Press, 1985, where he discusses his father's practice in rural New York and describes the layout of the house.

${ }^{7}$ Edward Shorter, 'The history of the doctorpatient relationship', in W F Bynum and R Porter
}

(eds), Companion encyclopedia of the history of medicine, vol. 2, London, Routledge, 1993, pp. 783-800, esp. pp. 787-92.

${ }^{8}$ George Bernard Shaw, The doctor's dilemma: Getting married, \& The shewing-up of Blanco Posnet, London, Constable, 1930. The play was first performed in 1906, but first published in Britain in 1911 as The doctor's dilemma: a tragedy (Harmondsworth, Penguin). The preface thus dates from 1911. Shorter used the 1957 edition, the quotation appears on p. 797, op. cit., note 7 above. 


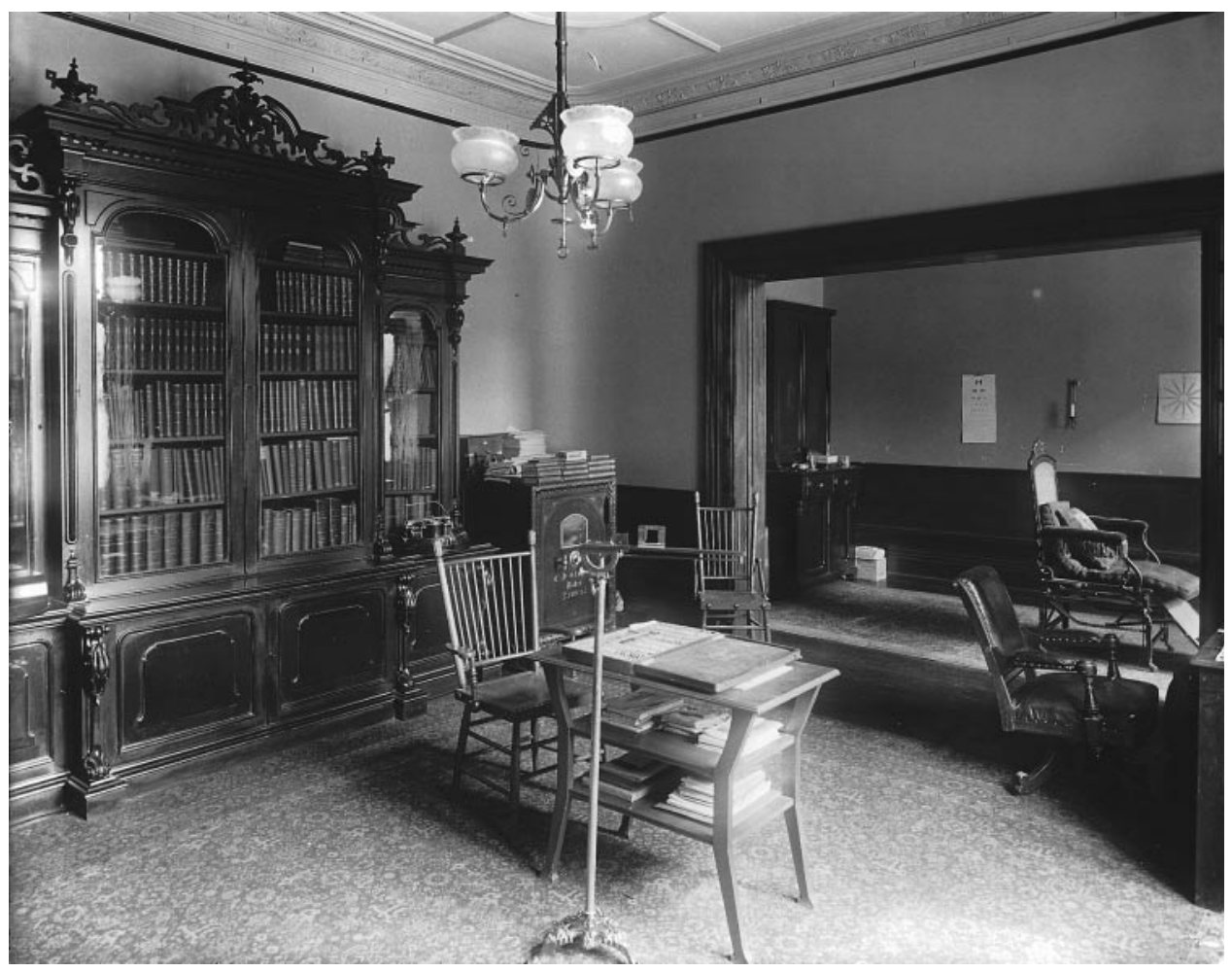

Figure 2: Dr Buller's consulting room, Montreal, QC, 1890. McCord Museum, Montreal, II-93206.

than the doctor's office". 9 The introduction of mass transit in urban centres (such as the streetcar) offered an important opportunity to modify this model of care, as patients could now reliably travel to a physician's office. Further structure was instilled with the advent of the telephone which, according to Paul Starr, "made it much easier for patients to see physicians at their offices at a prearranged time, reducing the risk of dropping in while the doctor was out on call; it also made office practice more attractive to doctors, who could now make orderly appointment hours and see more patients than when relying on an uneven stream, or trickle, to their door". ${ }^{10}$ The net result was an increased efficiency in health care delivery, at least from the perspective of physicians, who would appreciate the notable reduction in the portion of their work-day wasted on travel. Knox, Bohland and Shumsky argue that in America rising physicians' fees “must have been an incentive for people to substitute their own time for that of the doctor by travelling to his office instead of paying

\footnotetext{
${ }^{9}$ Neil Larry Shumsky, James Bohland, and Paul Knox, 'Separating doctors' homes and doctors' offices: San Francisco, 1881-1941', Soc. Sci. Med., 1986, 23: 1051-7, on p. 1054.
} 


\section{The Architecture of Home-offices for Physicians in Toronto, 1885-1930}

him an extra fee to visit them at home". ${ }^{11}$ In Toronto, the first horse-drawn streetcars and sleighs (winter) were introduced in 1861 and the first electric streetcars appeared by $1892,{ }^{12}$ both enhancing the potential success of the home-office. Knox, Bohland and Shumsky further argue that the transition of health care away from family-centred care to scienceand technology-driven approaches, with associated specialized equipment and a greater reliance on paramedical assistants and clerical support, meant that physicians needed their own space, a dedicated medical office space, to house this new approach. ${ }^{13}$

The era of home visits overlapped with the advent of home-offices. Sometimes physicians would continue to practise both models of patient care, as circumstances demanded. One of the physicians in our study, Dr Herbert J Hamilton, began his Toronto practice in 1894 and commissioned a purpose-built home-clinic in 1906, the same year that he became an elected member of the senate of the University of Toronto. Hamilton died in 1920 (aged fifty-five), reportedly falling victim to influenza towards the end of the Spanish flu pandemic. ${ }^{14}$ He had been sick for some three weeks before his death, but carried on with his duties and died shortly after collapsing in the home of a patient he was treating for the flu. This detail of his last days, captured in a newspaper account of his death, highlights the fact that even urban physicians who had committed to the home-office model of medical practice would still home-visit, particularly if patients were too ill (or incapacitated) to travel to the physician's office.

Secondly, we argue that the location of the house-offices foreshadowed and perhaps facilitated the development of Canada's most coherent hospital district. Harley Street in London $^{15}$ and the Longwood Medical and Academic Area in Boston are examples of the same sort of area in Britain and the United States. For scholars who study vernacular architecture, this relationship between the house-office and the city is an important reminder that less visible, hybrid, non-monumental buildings may be as significant or interesting as monuments, in this case hospitals. ${ }^{16}$ Toronto's 1892 Victoria Hospital for Sick Children (later called the Hospital for Sick Children) (Figure 3), located at the heart of the cluster of the house-offices explored in this paper, was a central node for professional and social networking among medical professionals in turn-of-the-century and today's Toronto. ${ }^{17}$ Significantly, this historic postcard of the institution includes two streetcars. We speculate

\footnotetext{
${ }^{11}$ Paul Knox, James Bohland, and Neil Larry Shumsky, 'The urban transition and the evolution of the medical care delivery system in America', Soc. Sci. Med., 1983, 17: 37-43, on p. 41.

${ }^{12} \mathrm{http}: / /$ www.toronto.ca/ttc/history.htm\#looking; abstracted from Mike Filey, The TTC story: the first seventy-five years, Toronto, Dundurn Press, 1997.

${ }^{13}$ Knox, Bohland, and Shumsky, op. cit., note 11 above, p. 41.

${ }^{14}$ Hamilton was born in Peel County, the son of a well-known farmer and local politician, and educated at Brampton High School and Trinity College, from which he graduated in medicine in 1885. He moved to Toronto in 1894 (house plans dated 1906) and joined in practice with Dr W P Caven and was a physician at the St Andrew's Hospital. In addition to becoming
}

a senator of the University of Toronto, Hamilton served as secretary of the Academy of Medicine. 'Leading medico dies of pneumonia', World, 6 February 1920, Herbert J Hamilton, Scrapbook A73-0028/136(07), University of Toronto Archives.

${ }^{15}$ See Charlotte Humphrey, 'Place, space and reputation: the changing role of Harley Street in English health care', Social Theory \& Health, 2004, 2: $153-69$.

${ }^{16}$ On the importance of studying medical buildings, see J T H Connor, 'Bigger than a bread box: medical buildings as museum artifacts', Caduceus, 1993, 9 (2): 119-30.

${ }^{17}$ It is difficult to say which came first without a comparative survey of earlier directories and censuses (e.g., the 1881 census). 
Annmarie Adams and Stacie Burke

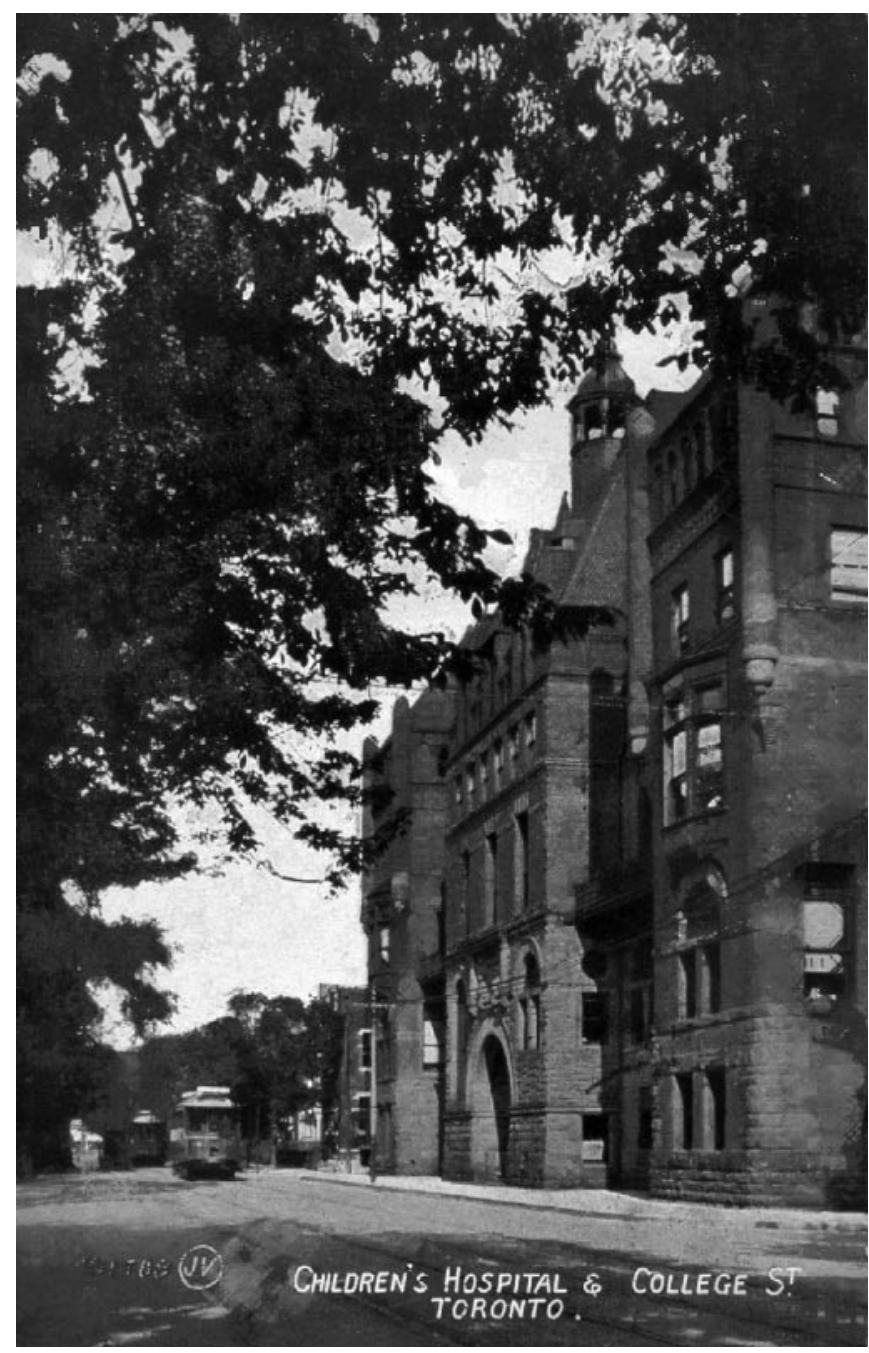

Figure 3: Postcard of the Victoria Hospital for Sick Children, Toronto. Collection Annmarie Adams.

that if physician home-offices were strategically placed to take advantage of easy access for patients, then the same advantages would accrue for the hospitals that came later. Many of Toronto's hospitals, particularly those for women and children, started off in private homes, as was the case in cities across North America, another significant link between houses and hospitals. ${ }^{18}$

\footnotetext{
${ }^{18}$ Annmarie Adams, Medicine by design: the architect and the modern hospital, 1893-1943,
}

Minneapolis, University of Minnesota Press, 2008, ch. 4 , pp. $89-108$ 


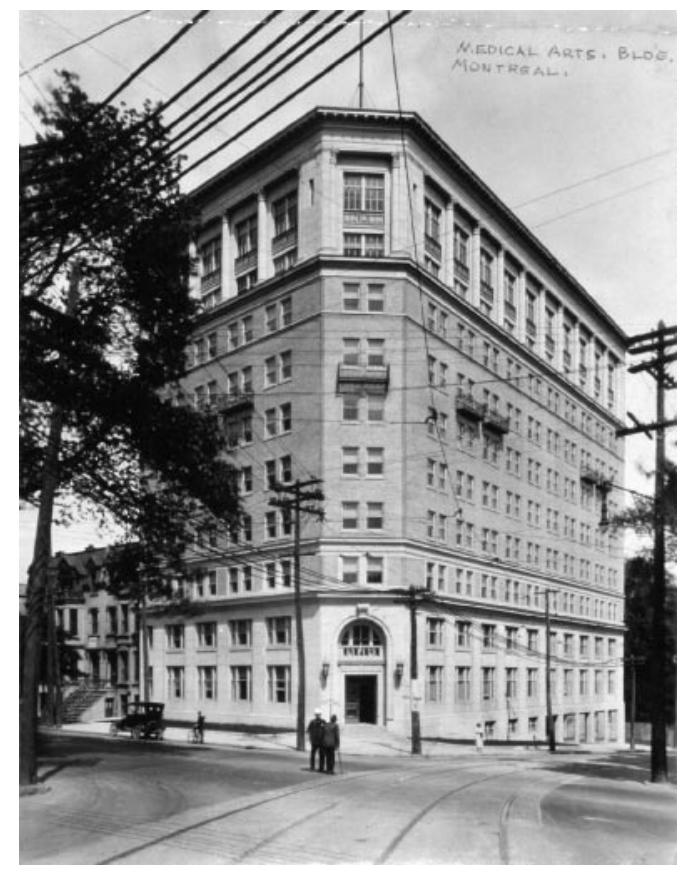

Figure 4: Medical Arts Building, Montreal. ARCH25040, Ross \& Macdonald Fonds. Collection Centre Canadien d'Architecture/Canadian Centre for Architecture, Montréal.

Our third sub-argument suggests that the end of the house-office era in large urban centres is unambiguous, ${ }^{19}$ marked in architectural terms by the introduction of a second, under-studied building type: the non-residential medical office, such as Montreal's Medical Arts Building of 1922 by Ross \& Macdonald (Figure 4). The Montreal Star claimed this comprehensive establishment to be "the first modern building in Canada designed exclusively for physicians, surgeons, dentists and allied professional men". ${ }^{20}$ Similar buildings would appear in Toronto and Vancouver ${ }^{21}$ eight years later, upstaging and replacing, we argue, the hybrid house-office typology. Studying an architectural typology - the home-office - as it disappears and is eclipsed by another architectural form - the medical high-rise - is a rare and welcome opportunity.

\section{Exterior Appearances and Internal Relations}

How did urban physicians combine their personal and professional lives in these unique buildings? Like the residences of notaries, music teachers, and other home-based professionals, family and work realms overlapped considerably. ${ }^{22}$ The nine medical examples for

\footnotetext{
${ }^{19}$ Jennifer Connor notes that the house-office tradition persisted outside geographic centres like Toronto, Montreal, and London. Personal correspondence, 31 Mar. 2005.

${ }^{20}$ Montreal Star, 25 Jan. 1922.
}

\footnotetext{
${ }^{21}$ See 'Medical-Dental Building, Vancouver, B.C.', Journal of the Royal Architectural Institute of Canada, June 1930, 7: 206-11.

${ }^{22}$ Sherry Olson points out that notaries' wives functioned as receptionists and book-keepers in
} 
which we have detailed architectural drawings, such as Dr Dumble's house by the architects Burke, Horwood and White (Figure 5), appeared from the street as ordinary Victorian houses. In examples highlighted in this paper, the medical mandate of the building is expressed inside, especially in plan, where labs and waiting, consulting, and operating rooms were positioned across the front of the dwelling, or along one side of long and narrow urban houses. Pocket doors were especially common as a way of separating adjacent, ground-floor rooms in urban Victorian houses such as front and back parlours, or parlours and dining/sitting-rooms. In the Dumble house, for example, the doctor's waiting-room is separated from the family's dining-room (and the hallway) only by pocket doors. As they slide along their length and seemingly vanish into interior walls, pocket doors save valuable space. The disappearing doors allowed these double rooms to function in multiple ways, both as large, extended spaces, or on their own as more intimate rooms. The architectural historian Jan Jennings points out that the extended configuration facilitated by pocket doors made it possible to accommodate social diversions that were significant features of Victorian family life, such as musical gatherings and parties. ${ }^{23}$ These doors also made it unnecessary to enter the more public hall of Victorian houses, as one could move from room to room directly through the wide, unobstructed openings that framed pocket doors. ${ }^{24}$ That Dr Dumble's family dining-room and waiting-room were linked by an opening 5 feet 6 inches wide and separated only by pocket doors is powerful evidence of the proximity of medical practice and family life in the era of the home-office.

Functional zoning was another strategy employed to separate family and patients. In Dr Herbert J Hamilton's house (Figure 6) of 1906 the architect's strategy was to separate the domestic and professional zones to the left and right of the entry hall. In all cases, despite variations in the plan configurations, the medical function of the house was completely disguised on the exterior of these structures.

The efforts made to mask the commercial mandate of the house are particularly clear in examples of renovations from house to house-office. In the case of Dr Horace E Eaton's home (Figure 7), the doctor hired Burke and Horwood to transform a large front room into two operating rooms and a waiting-room in 1905. They accomplished this transformation with considerable skill and modesty by subtly adding a new Palladian window arrangement to hide the existence of the two small operating rooms behind. ${ }^{25}$ The new window for the operating rooms fits well with the existing arched doorway and simple, untouched arched window that illuminated the waiting-room, retaining the appearance of a single, large room in the front of the house. A passerby would likely never know, in other words, that the front rooms were divided or that they housed a medical practice.

Montreal and that in Paris lawyers still today have an office at home and the family's salon doubles as a waiting-room; personal correspondence, $23 \mathrm{Feb}$. 2005. Jennifer Connor, on the other hand, thinks that many physicians may have carved out even more separate space for patients; personal correspondence 31 Mar. 2005. She cites the rural house-office in Lucknow, Ontario, described by the general practitioner William Johnston in Before the age of miracles: memoirs of a country doctor, Toronto,
Fitzhenry and Whiteside, 1972, which was an extension to the house (see pp. 19, 53, 106).

${ }^{23}$ Jennings, op. cit., see note 2 above, p. 178.

${ }^{24}$ A superb analysis of spatial flow and circulation in typical Victorian homes is found in ibid., pp. $167-81$.

${ }^{25}$ A Palladian window has a high, round-topped central section and two lower, square-topped side sections. 


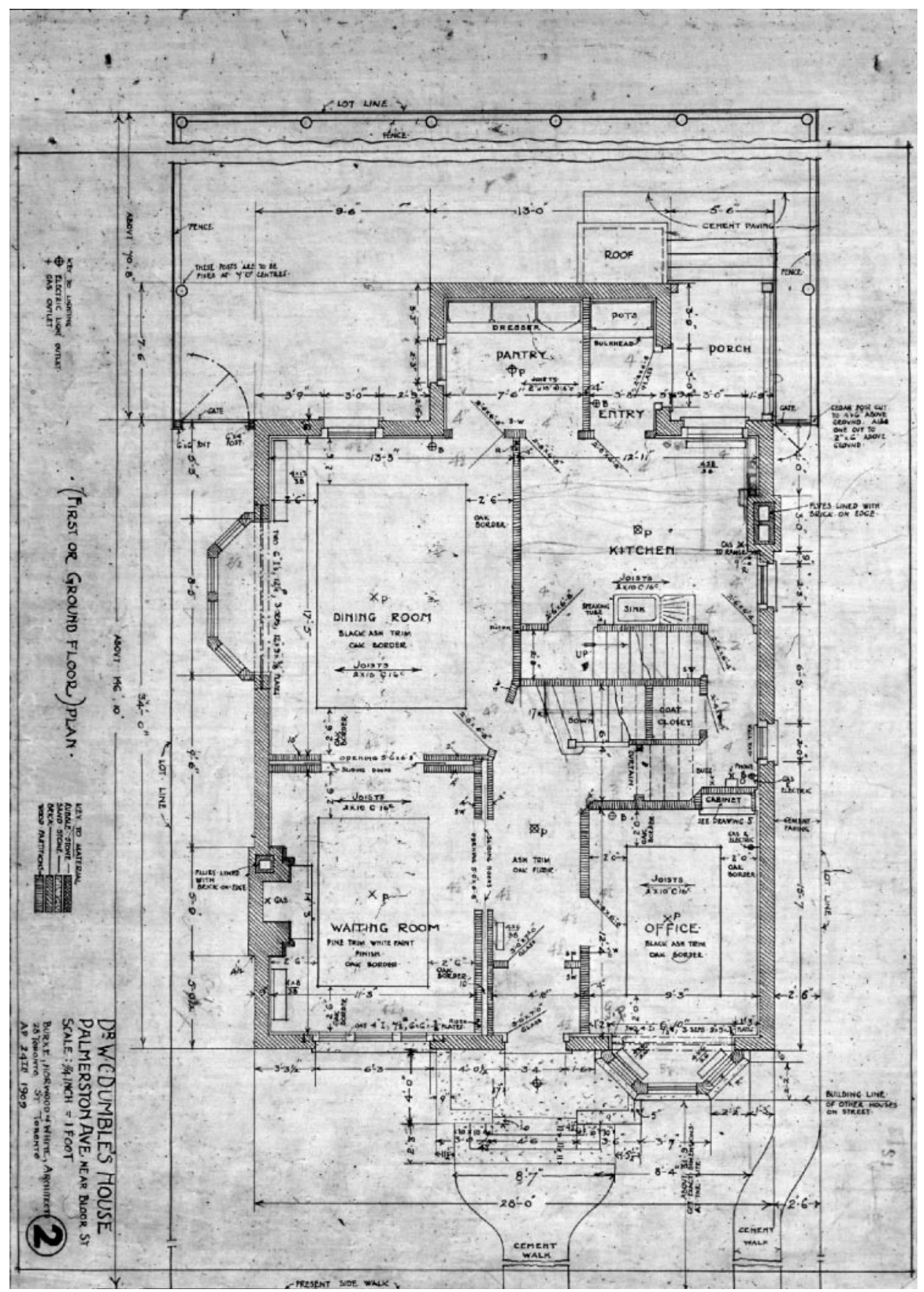

Figure 5: Ground floor plan of the home-office of Dr William C Dumble, Toronto. Archives of Ontario, C 11-325, (1030) 17. 


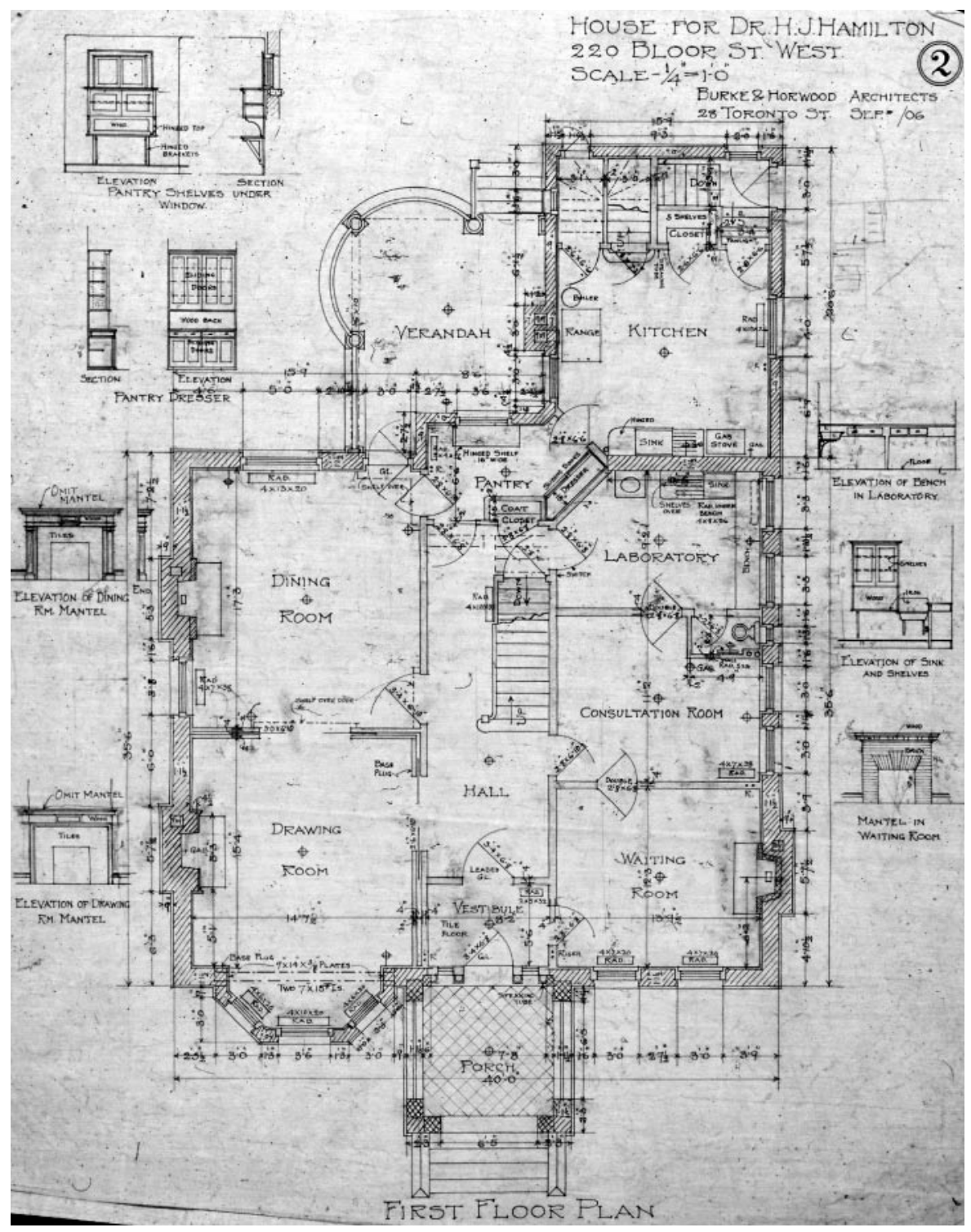

Figure 6: Ground floor plan of the home-office of Dr Herbert J Hamilton, Toronto, 1906. Archives of Ontario, C 11-1133, (921) 15. 


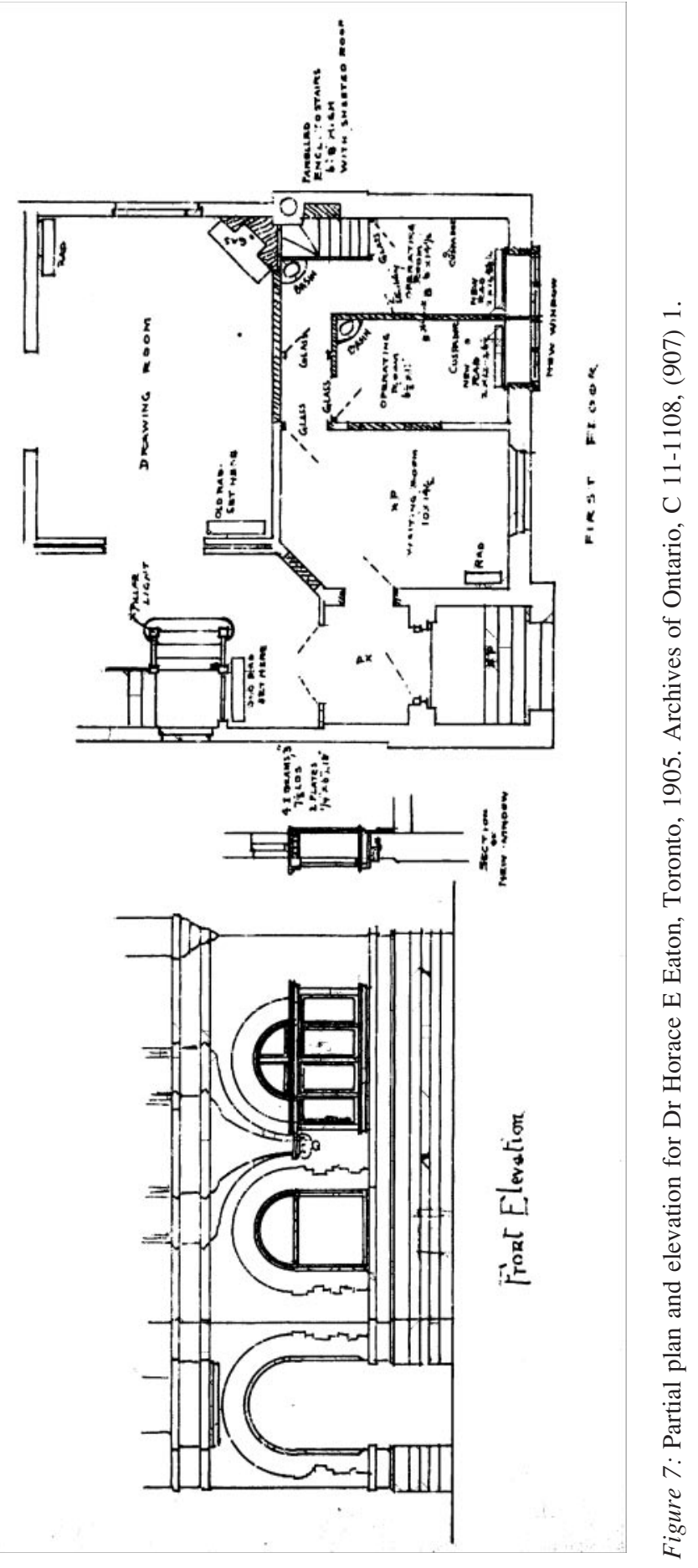

173 


\section{Annmarie Adams and Stacie Burke}

\section{Separate and Together}

Amongst our earliest examples of doctors' home-office plans are alterations designed for Dr J E Graham (1885) by Langley \& Burke Architects and a proposed residence for Dr Henry Machell (1886) by the architect David Brash Dick. Langley \& Burke presumably transformed Graham's double parlour, to the left of the entry, into a waiting-room and a surgery, again separated by pocket doors (Figure 8). A sophisticated double vestibule arrangement, labelled "new" on the architects' elegant, water-coloured plan, restricted patients' movement to the office area of the home. Still, a generous dining-room and a

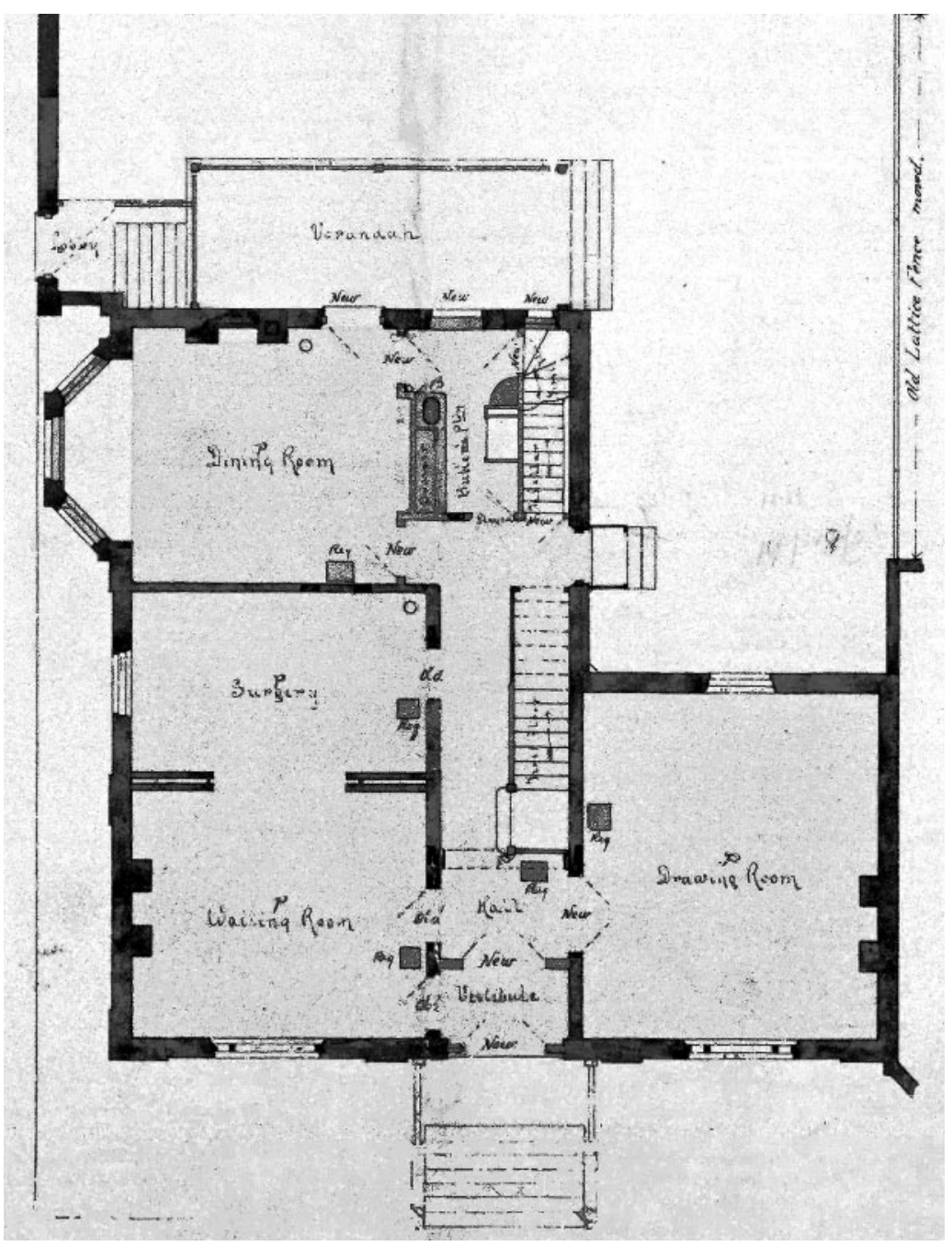

Figure 8: Detail of plans for Dr J E Graham, Toronto, 1885. Archives of Ontario, C 11-513, (481) 1. 


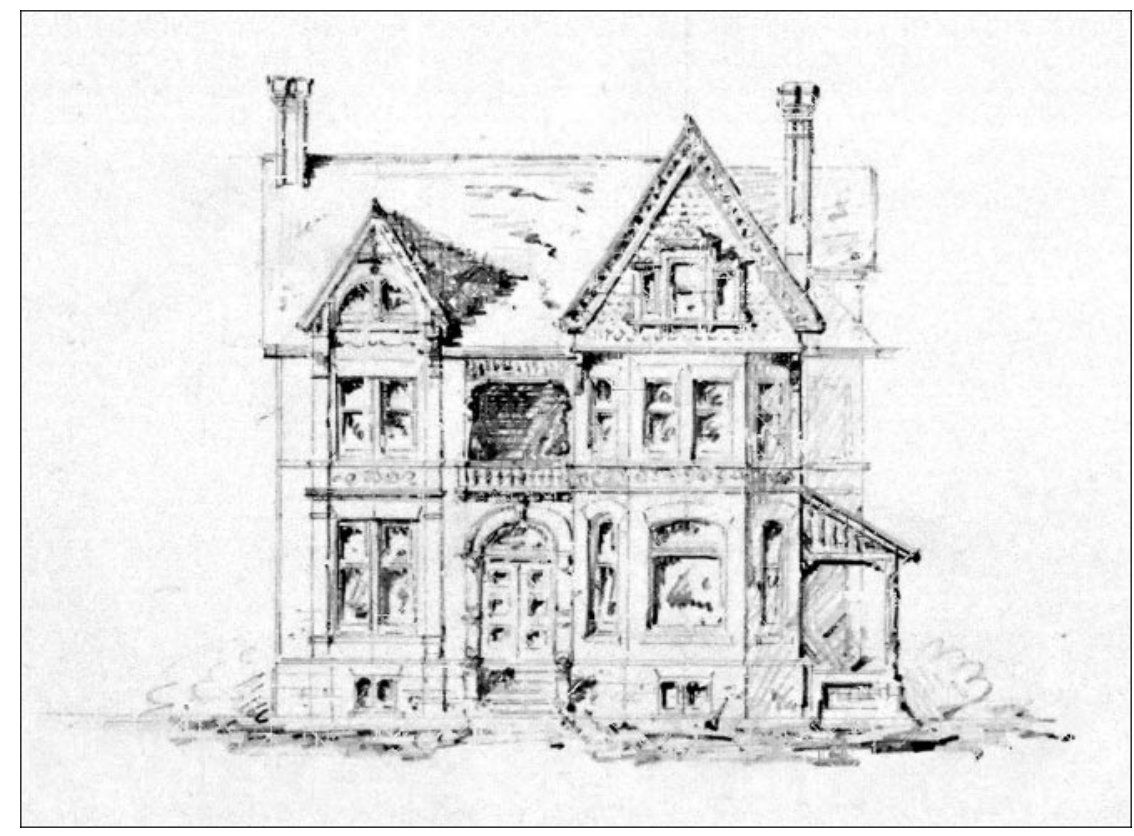

Figure 9: Detail of elevation for Dr Henry T Machell, Toronto, 1886. Archives of Ontario, C 11-257, (262a) 1.

drawing-room occupied the same floor as the doctor's practice. We know that James Elliott Graham received his MD degree in 1870 and died in 1899 aged fifty-two. William Osler, Graham's famous classmate at the Toronto Medical College in 1868-69, described him as "the first Canadian who had the courage to cut himself off from family practice and devote his time to consultative and research work". ${ }^{26}$ Already fifteen years into his medical career when he commissioned his home-office, Graham was one of the earliest physicians in our group attracted to the advantages of home-office consultations. A few years after establishing his home-office, Graham joined the University of Toronto's Faculty of Medicine in 1893 as professor of clinical medicine. It is an intriguing possibility that Graham represented the emerging class of independent specialist physician described by Donald Madison for the United States, ${ }^{27}$ a new category of consulting departing from routine general practice. These new medical professionals may have contributed to the rise of the home-office model of practice in Toronto.

Dick drew up two sets of plans in configuring the house-office of Dr Henry Machell ${ }^{28}$ (Figure 9), experimenting with connecting the surgery and waiting-room separately from

\footnotetext{
26 'Honored dead colleague', Globe, 19 Dec. 1906, James Elliott Graham, Scrapbook A73-0026/ 124(12), University of Toronto Archives.

${ }^{27}$ Donald L Madison, 'Preserving individualism in the organizational society: "cooperation" and
}

American medical practice, 1900-1920', Bull. Hist. Med., 1996, 70: 442-83.

${ }^{28}$ Henry Thomas Machell died on 9 Nov. 1930, aged eighty-one. He was head of medical services at the Hospital for Sick Children, served on the staff of 


\section{Annmarie Adams and Stacie Burke}

the family space. Like the Graham plan, the Machell household could be effectively isolated from patients simply by closing an inner vestibule door. The doctor's practice occupied the left side of the central hall, while the family spaces were on the right. A narrow passageway, located behind the family's stair, linked the patients' waitingroom with a surgery. A rather ingenious sequence of interior doorways presumably shut off the family space from the practice.

Dr Thorburn's house-office of 1891 (Figure 10), also by Dick, is one of the few in the sample to include an entirely independent side entrance for patients, allowing them to enter directly into the heart of the house with no overlap whatsoever with the more private family spaces. In this case the rooms given over to medical practice were a waiting-room, a consulting room and a small laboratory, each with a window. In 1901 the Thorburn household included the doctor, his wife Jane, and his adult unmarried daughter Georgina. Jane Roseman and Julia Malloy were employed and living in the home as a domestic and a cook respectively. Not surprisingly, Dick's design includes two servants' bedrooms above the kitchen. Also in the family home was Ernest McPhee, thirteen years of age, who had emigrated from England in 1900. According to the census, this was just one of three dwelling houses owned by Thorburn, along with 600 acres of real estate.

It is important to note that even these early examples have generous waiting-rooms that occupy a substantial percentage of the medical practice area. Some waiting-rooms, such as Dr Dumble's, occupied nearly 25 per cent of the ground floor of his house; and many included finely finished fireplaces with mantles, like the one that shows in Dr Hamilton's plan. In Dr Eaton's house-clinic, the waiting-room is larger than either of the two operating rooms. The presence of these elaborate spaces for waiting may imply that the physicians anticipated seeing multiple, overlapping appointments in a single time period, reinforcing the idea that doctors were increasingly turning to a business-based, time-centred model and away from the more haphazard experience of being called to patients' homes. At the same time, these waiting-rooms also provided comfortable spaces for a patient's family or companions to wait during consultations.

It is likely that the distinct spatial separation observed in our earliest plans generally diminished over time, as there is a striking fluidity between family life and practice in later home plans. As a case in point, in the much later 1905 Eaton house plan, and other examples, patients and family members shared a common entry sequence, but patients were then diverted immediately into the spaces devoted to practice. Sometimes the separation might be as minimal as a glass door. This openness and uninterrupted flow of space marks a departure from earlier examples where there seemed to be a preference for maintaining separation between the patients and the household, either through a separate access, like the Thorburn house, or fitting new passageways under staircases, as in the Machell plan.

When doctors retro-fitted houses as house-offices, public rooms moved upstairs and downstairs in order to accommodate waiting-rooms, surgeries and laboratories. In quite a few cases billiard-rooms were re-located to the basements, and sitting-rooms moved

St John's Hospital and was associate professor of obstetrics and professor of pediatrics (professor emeritus at time of death) at the University of Toronto.
See Globe, 10 Nov. 1930; Star, 6 Dec. 1930; Henry Thomas Machell, Scrapbook A73-0026/272(25), University of Toronto Archives. 


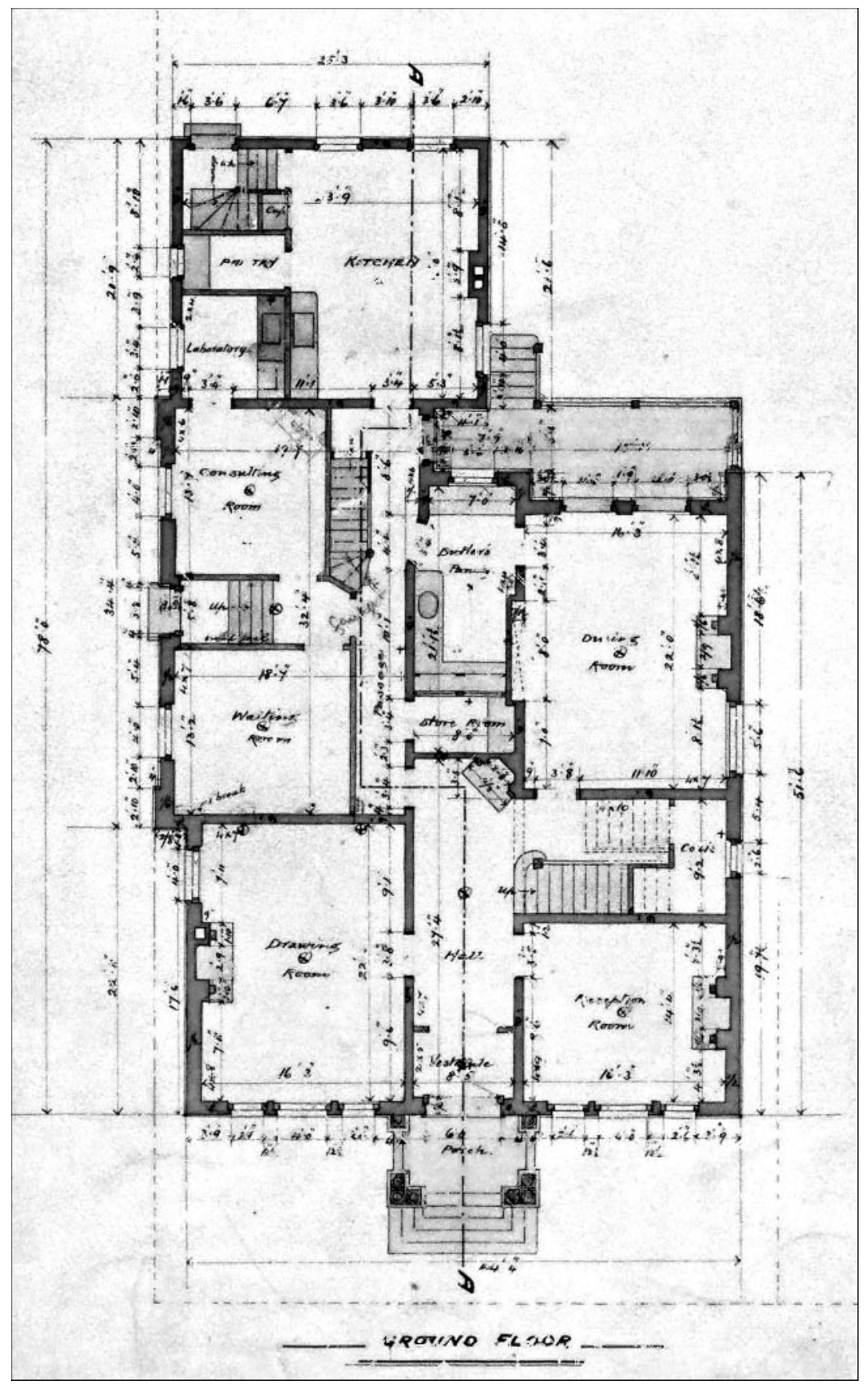

Figure 10: Detail of plans for Dr James Thorburn, Toronto, 1891. The entrance for patients is at the centre left of the plan. Archives of Ontario, C 11-310, (325) 6. 


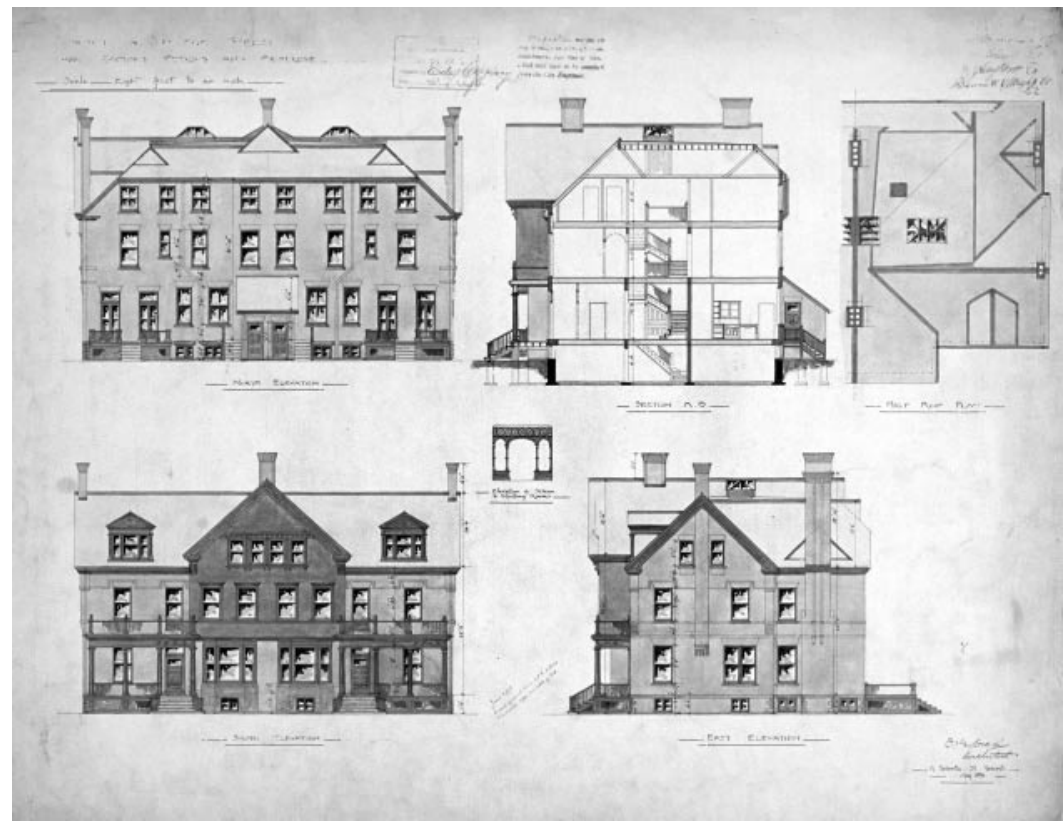

Figure 11: Detail of duplex elevation for Drs Peters and Primrose, Toronto, 1898. Archives of Ontario, C 11-360, (374) 2.

upstairs, suggesting a vertical displacement of family life as the medical practice came to occupy most of the ground floor. It is impossible to know from the architectural evidence whether families used waiting- and/or medical rooms for their own activities when they were not being used by the physicians. In all cases, however, even when the medical practices came to take over the ground floor, the kitchen always remained relatively inaccessible from the rooms dedicated to practice.

In the case study showing the greatest fluidity, two physicians' families lived side-byside in semi-detached homes. In 1898, Dr George A Peters, ${ }^{29}$ associate professor of clinical surgery (since 1890) at the University of Toronto, and Dr Alexander Primrose, ${ }^{30}$ University of Toronto professor of anatomy (since 1896) and associate professor of surgery (since 1897), commissioned a three-storey duplex from Dick at 100-102 College Street, with consulting and waiting-rooms occupying the first two rooms on the exterior walls of each twelve-room dwelling (Figures 11-12). Note that in the Peters-Primrose plan consulting and waiting-rooms were entered from the same hall that family members would use to enter the drawing-room or to access the staircase to the more private rooms of the upper level,

${ }^{29}$ Guelph Mercury, 19 Aug. 1960; Globe, 14 Mar. 1907; Mail, 15 Mar. 1907; Globe, 16 Mar. 1907; George Armstrong Peters, Scrapbook A73-0026/362(34), University of Toronto Archives.
${ }^{30}$ Varsity, 9 Feb. 1944; Toronto Telegram, 5 Apr. 1944; St. Thomas Times Journal, 12 Feb. 1944; Pictou Advocate, 10 Feb. 1944; plus many more in Alexander Primrose, Scrapbook A73-0026/368(86), University of Toronto Archives. 


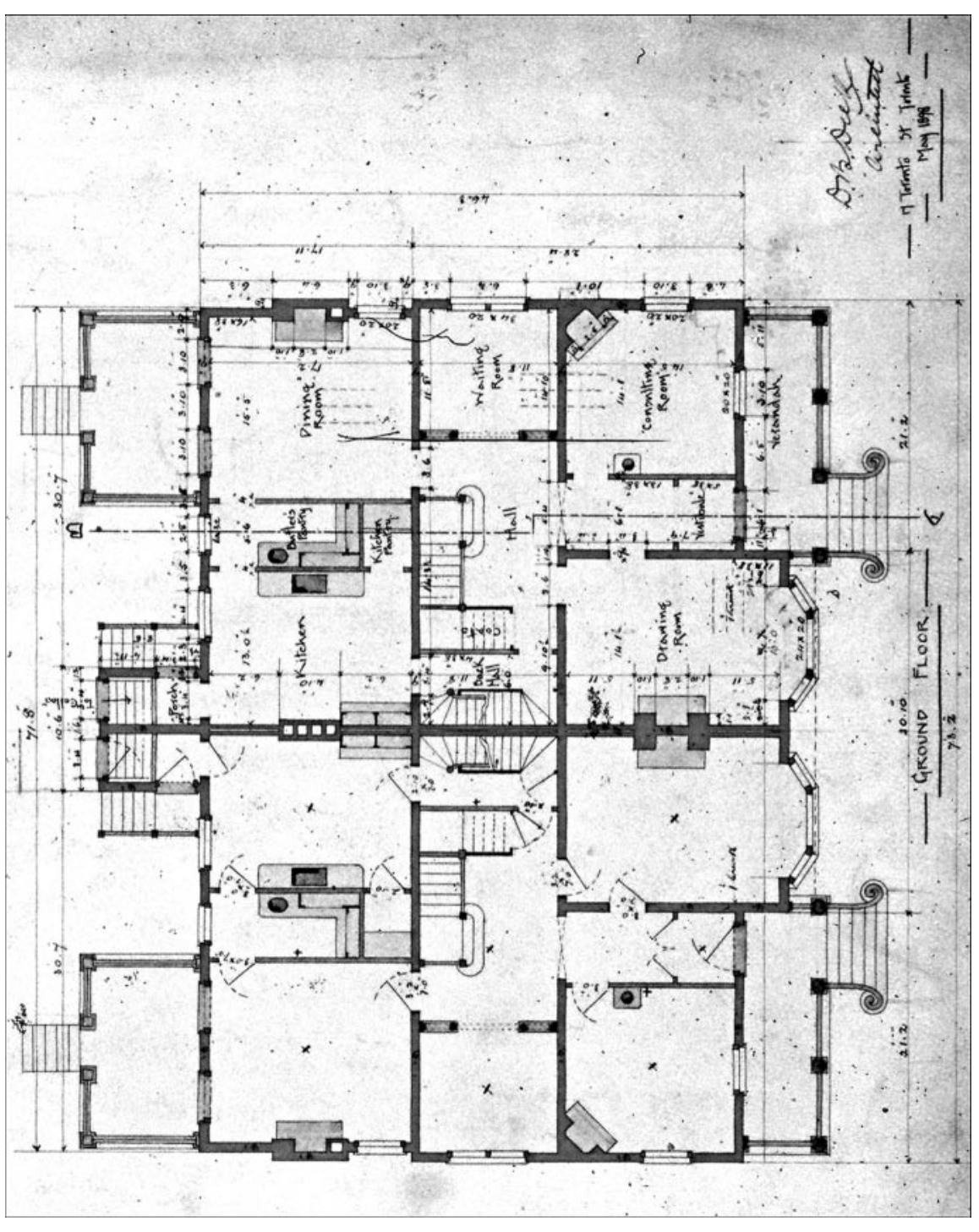

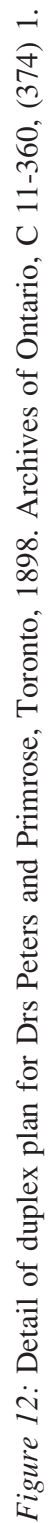




\section{Annmarie Adams and Stacie Burke}

with no separation whatsoever. In a surprisingly open situation, the doctor's waiting-room occupies the heart of the family home with an extra wide doorway that looks onto the staircase. Again, only pocket doors separate the waiting-room from the hall and there is no direct connection between the waiting-room and the consulting room. Patients would thus enter the family hall twice, once to go into the waiting-room and then again to see the doctor in the consulting room.

Both Peters and Primrose were surgical specialists, a medical niche perhaps facilitated by their urban environment. Both men remained in Toronto following their medical training, though their early lives were spent in rural locales (Peters was born in Eramosa, Ontario; Primrose was born in Pictou, Nova Scotia). Peters and Primrose were not only neighbours and colleagues in surgery, but also friends, as Primrose was one of eight pallbearers at Peters' funeral. ${ }^{31}$

Peters became a Fellow of the Royal College of Surgeons in England in 1890 and Primrose became MRCS in 1888 and FRCS in 1925. At his untimely death at age fortyeight in 1907 (attributed to heart trouble), Peters was described as a "genius as a surgeon"; seven years earlier, he reportedly gave up his academic appointment in order to transfer "the whole of his attention to the surgical side of his calling". ${ }^{32}$ Primrose's association with the University of Toronto intensified over time, particularly following his return from service as a Consultant Surgeon for a Canadian Forces hospital in Greece during the First World War. He was dean of the Faculty of Medicine from 1920 to 1932. Indeed, Primrose's spatial trajectory took him from rural boyhood to the administration of one of Canada's most prestigious medical and educational urban institutions.

\section{Location, Location, Location}

The Peters-Primrose duplex was located on College Street, in the core of what would become arguably Canada's most coherent hospital district. In order to study the distribution of doctors practising within Toronto, home and office addresses were collected for the 342 physicians who advertised in Might's Toronto City Directory, 1901. Mapping the addresses of the 311 (91 per cent) who practised out of their home offices highlights a significant clustering of these physicians, particularly on east-west running College and Bloor Streets, and the north-south artery of Spadina Avenue (Figure 13). The highest concentration of doctors' homes (almost 80 per cent) were located within a two kilometre radius of the cluster of health care buildings on College Street between University Avenue and Yonge Street (Toronto's main commercial street), including: the Hospital for Sick Children, the Dental Institute, the Dental Infirmary, and the Nursing at Home Mission. In comparison, only a handful of doctors' homes were situated in the immediate vicinity of more

\footnotetext{
${ }^{31}$ Globe, 14 Mar. 1907, George Armstrong Peters, Scrapbook A73-0026/362(34), University of Toronto Archives. Peters' importance in the medical community and at the university is reflected by the fact that Maurice Hutton, Esq., acting president of the University of Toronto, also served as pallbearer in a funeral procession that included " 21 carriages filled
}

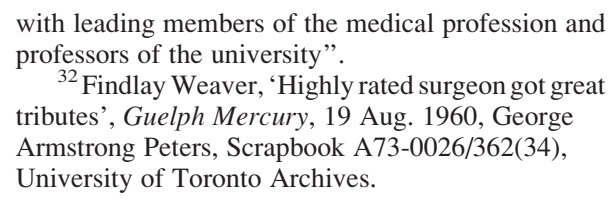

with leading members of the medical profession and professors of the university".

${ }^{32}$ Findlay Weaver, 'Highly rated surgeon got great tributes', Guelph Mercury, 19 Aug. 1960, George Armstrong Peters, Scrapbook A73-0026/362(34), University of Toronto Archives. 


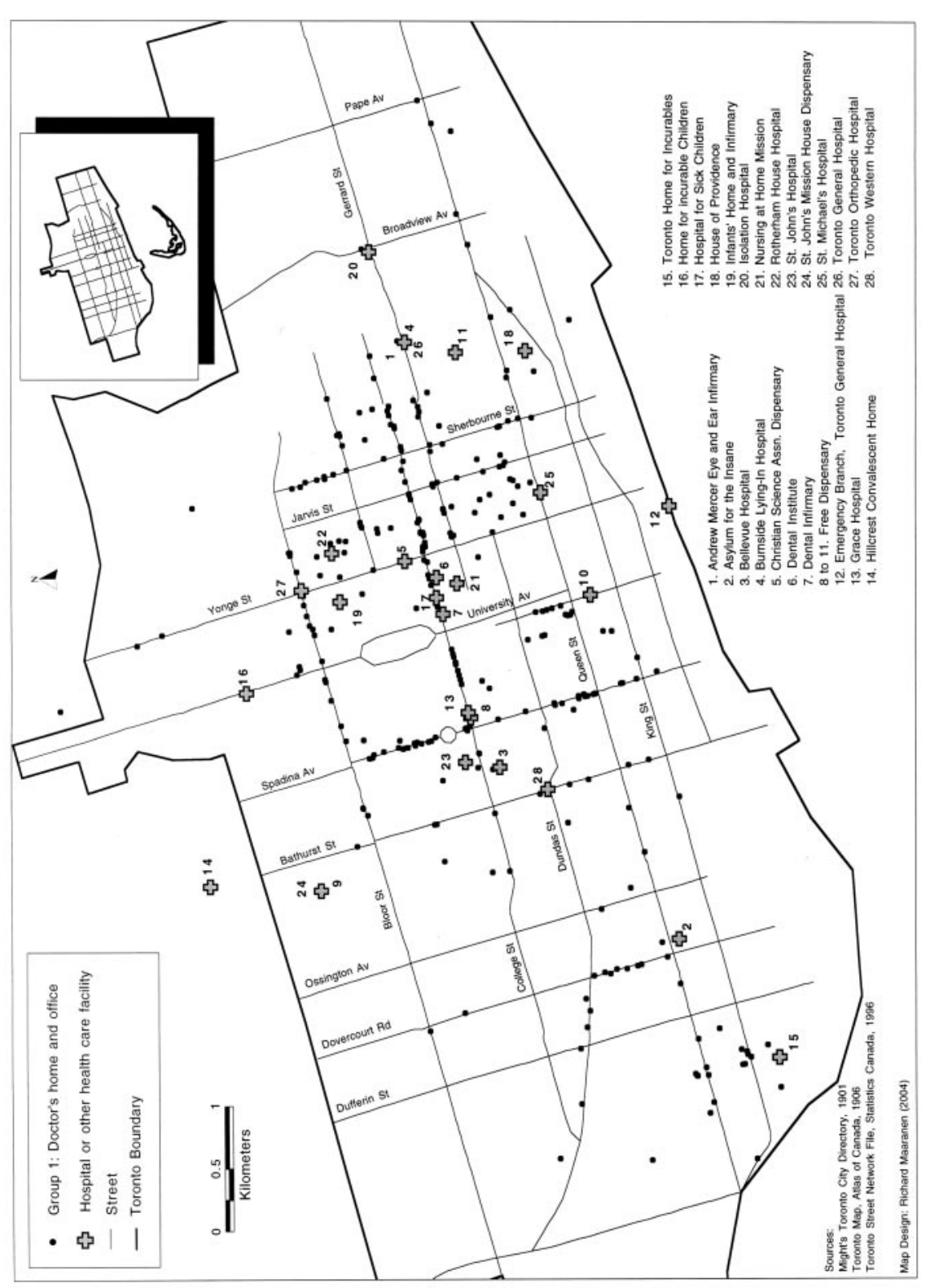

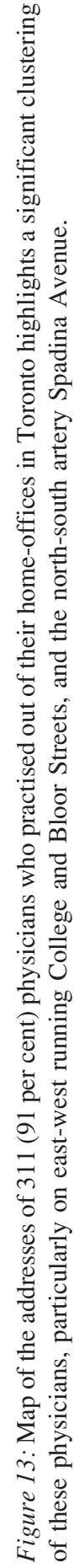




\section{Annmarie Adams and Stacie Burke}

strategically peripheralized or long-term care facilities such as the Isolation Hospital, the Toronto Home for Incurables, the Hillcrest Convalescent Home, and the Asylum for the Insane. Also tied to this core area, only a short distance away, were two powerful institutions: the University of Toronto and its associated medical school, located to the immediate west of Ontario's Queens Park provincial legislative buildings (which opened within the oval loop in 1893).

The locations of the remaining 31 (9 per cent) Toronto doctors who advertised separate home and office addresses in the Directory were also mapped (Figure 14). In this map we distinguish between Group 2 doctors, the 28 doctors with separate home and office addresses, and Group 3 doctors, the remaining three who advertised home-office as well as separate office addresses. Using home address and office address, the average distance travelled by "commuting" physicians was approximately 1.5 kilometres each way. Dr Herbert Galloway undertook the shortest commute, estimated at 2 metres, between his residence at 14 Bloor Street East and his office at the Toronto Orthopaedic Hospital located at 12 Bloor Street East. Dr John T Duncan undertook one of the longer commutes, about 5 kilometres each way, between his home at 32 Fuller Avenue (the more southerly of the two black dots located towards the bottom left-hand corner of the map) and 39 Bloor Street East (the black triangle located to the immediate right of No. 27 the Toronto Orthopaedic Hospital).

Interestingly, the Toronto General Hospital does not figure prominently in this snapshot of the centralization of health care in Toronto in 1901. At this time, the TGH was located to the east and outside of the core area, on Gerrard Street (No. 26 on the map). This distance between the TGH and the hub of medical activities in the city would not last, however, as the hospital relocated in 1913 to its present site on the southeast corner of College Street and University Avenue (Figure 15). ${ }^{33}$ In his fine history of the institution, J T H Connor suggests that this move was motivated by the opening of the new Faculty of Medicine building at the University of Toronto in $1903 .{ }^{34}$ Medical and academic centralization in this area of the city continued to intensify over time as more hospitals opened or relocated to the district. In 1951, for example, the Hospital for Sick Children moved from its location at the corner of Elizabeth and College Streets, as it appears as No. 17 on the map, to its present location at 555 University Avenue, with major additions in the 1950s and 1990s. In 1953, Mount Sinai Hospital relocated to 550 University Avenue from its previous site on Yorkville Avenue. In 1995, Princess Margaret Hospital relocated to 610 University Avenue from its former Sherbourne Street site. The College Street/University Avenue nexus of major health care facilities and doctors' home-offices was sufficiently intense to consider this a medical-service driven neighbourhood. Similar clusters of health care professionals have been observed in other cities. Sometimes these clusters also moved in a cohesive fashion as cities expanded and developed over time. The geographers Sherry Olson and David Hanna, for example, noted that as Montreal grew during the nineteenth

\footnotetext{
${ }^{33}$ Humphrey (op. cit., note 15 above, p. 155) notes how the construction of hospitals near London's Harley Street "acknowledged and consolidated" its health care focus.
}

\footnotetext{
${ }^{34} \mathrm{~J}$ T H Connor, Doing good: the life of Toronto's General Hospital, University of Toronto Press, 2000, p. 187.
} 


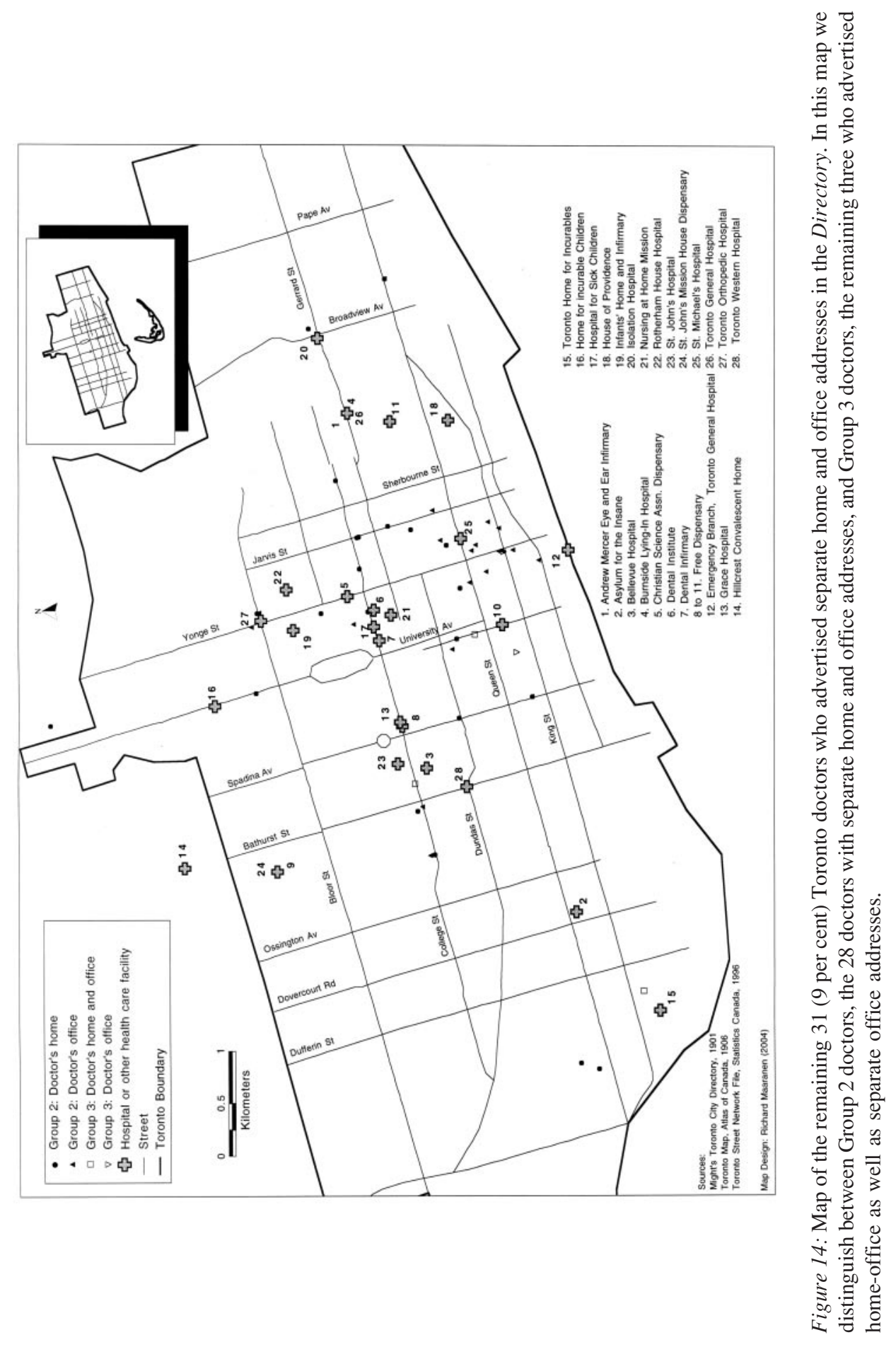




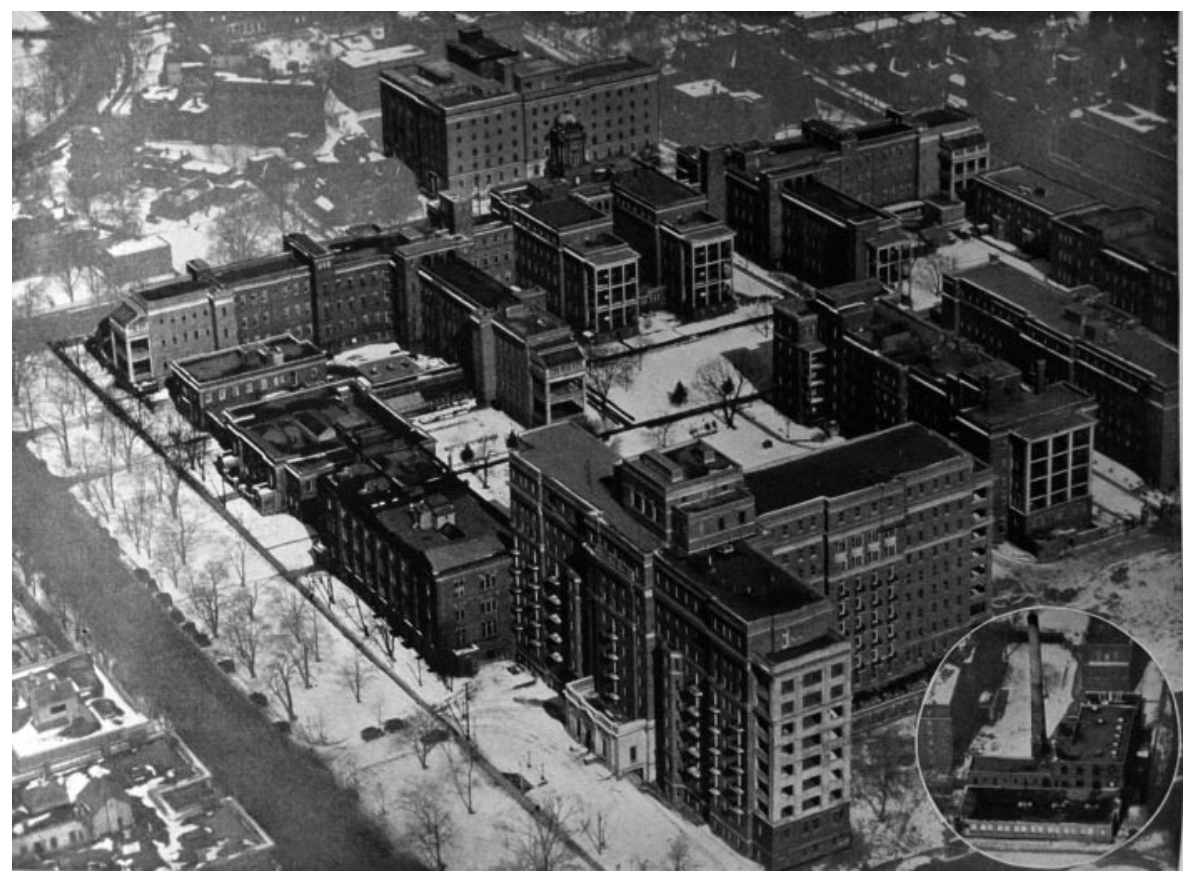

Figure 15: Aerial photograph of the Toronto General Hospital. Canadian Hospital, May 1930: 24.

century, doctors, dentists and other professionals began to move out of Old Montreal and into other neighbourhoods, including those that began to climb Mount Royal. ${ }^{35}$

\section{Physicians in the 1901 Census}

Nominal census returns are an invaluable aid to allow us to determine the overall household arrangements established by these physicians operating home-offices. Once we transcribed physicians' addresses from Might's Directory, we located the majority of those who operated home-offices in the 1901 census returns. A total of 244 (78 per cent) of the 314 physicians who advertised home-based practices (exclusive home-based $n=311$, and home-office in combination with an offsite office, $n=3$ ) were located in a householdby-household search of returns for Toronto in the 1901 Census of Canada. This detailed search also revealed a number of individuals claiming occupations of physicians and surgeons who did not advertise in Might's Directory. It is possible that these could be doctors employed in hospitals or charitable clinics operated by the city, doctors employed

\footnotetext{
${ }^{35}$ Sherry Olson and David Hanna, 'Social change in Montreal, 1842-1901', in R Louis Gentilcore, Don Measner and Ronald H Walder (eds), Historical
}

atlas of Canada: volume ii: the land transformed, 1800-1891, University of Toronto Press, 1993, Plate 49. 


\section{The Architecture of Home-offices for Physicians in Toronto, 1885-1930}

as instructors, demonstrators, or professors at medical schools and clinics in the city, physicians retired from active practice, or physicians who recently relocated to Toronto.

Of the 244 physicians found, 95 per cent $(n=232)$ and 5 per cent $(n=12)$ were male and female physicians and surgeons respectively. Although Might's Directory has listings for only a handful of female physicians relative to male physicians, a number of notable female physicians were captured in these listings. Included are mother and daughter Dr Emily Stowe's and Dr Augusta Stowe Gullen's home-offices at 463 and 461 Spadina Avenue (close to the intersection with College Street) respectively. Though trained (by necessity) in the United States, Stowe is recognized as the first woman to practise medicine in Canada. ${ }^{36}$ Not long after breaking a hip in 1893 , Stowe retired from practice. ${ }^{37}$ At the time of the 1901 census, then aged sixty-eight, she resided with her 38-year-old son Frank, a dentist, his wife Mary (aged thirty-four), their two daughters (Marie, eight, and Hilda, six) and son (Hudson, seven months), and Sarah MacLennoy, a 23-year-old domestic. It is puzzling that she continued actively to advertise a practice in 1901, even though her biographers suggest she had retired by this time. Stowe passed away only two years later, in 1903. Next door, at 461 Spadina Avenue, lived Stowe's daughter, Dr Augusta Stowe Gullen, also significant in Canadian history as the first woman to earn a Canadian medical degree (in 1883). Both Augusta and her husband, Dr John B Gullen, advertised their combined home-based practice. Living with them were Augusta's cousin (Emily Stowe) and Catharine Murphy, a domestic.

Women physicians lived in a range of familial and spatial situations. Emily Stowe was the only widowed female physician in the group of twelve women physicians advertising in Might's Directory. Along with Stowe Gullen there were three other married female physicians. Ida Lynd, forty-eight years of age, lived with her husband, a 53-year-old health inspector, their three children, two child "friends", and a servant. Lynd reported earnings of $\$ 3000$ a year, while her husband reported earnings of $\$ 600$ a year. Margaret Gordon, forty-two years, lived with her husband, a forty-year-old salesman (earning \$400 a year) and their two children. Jennie Coons, thirty, and her husband William Coons, twentyfour, and also a physician, boarded together in a home. The remaining seven female physicians were unmarried. Two lived in homes headed by their widowed mothers that included unmarried siblings. One woman lived in the home headed by her widowed father (no siblings). Julia Thomas, a 52-year-old single female physician, lodged in the home of a thirty-year-old piano maker and his family. Bertha Dymond, a 34-year-old surgeon, ran her own rooming house with a total of nine boarders recorded at the time of the census. Leila Davis, thirty-five years old and unmarried, was the only female physician living alone.

Returning to those physicians advertising home-offices in 1901, important findings emerge concerning ancestry and earnings. Overall, 99.2 per cent $(n=242)$ of the home-office physicians self-identified as Canadian. Most of the physicians were born in Canada (84.9 per cent, $\mathrm{n}=207)$, with a small number coming from England (6.6

\footnotetext{
${ }^{36}$ See Mary Beacock Fryer, Emily Stowe: doctor and suffragist, Toronto, Hannah Institute \& Dundurn Press, 1990.

${ }^{37}$ See Emily Stowe, Dictionary of Canadian Biography Online, Library and Archives, Government
}

of Canada, http://www.biographi.ca/EN/ShowBio. asp? BioId $=40926$. 
per cent), Scotland ( 2.5 per cent), Ireland ( 2 per cent), the United States ( 2 per cent), the West Indies ( 0.8 per cent), and "other" countries (1.2 per cent). 42.6 per cent of the physicians $(n=104)$ claimed English/Welsh ancestry, while 25.4 per cent and 24.2 per cent claimed Scottish and Irish ancestry respectively. Of the remaining physicians, 6.5 per cent claimed other European ancestry and 1.2 per cent were unknown. The mean age of the physicians who advertised home-based practices was 45.3 years $(\mathrm{sd}=12.6)$, with the youngest physician reported as twenty-three years old and the oldest as eighty-five. Only 34 of the 244 physicians reported their earnings to the census enumerator. We calculated mean earnings of $\$ 2041.18(\mathrm{sd}=\$ 1406.93)$ per annum among those who did report, with a minimum of $\$ 100$ (Dr Thomas Phillips, aged sixty-six) and a maximum of $\$ 7000$ (Dr James Cotton, aged thirty-nine).

Further insights can be gained into the nature and structure of home-office physician households from the 1901 nominal census returns. The mean household size was 5.3 $(s d=2.1)$ persons. Physicians living alone occupied the smallest households, while the largest non-institutional physician household included fifteen persons. From our sample of 244 physicians, 218 (89.3 per cent) self-reported as the head of their households. Of those remaining, 4.1 per cent $(n=10)$ were the son of the head, 1.2 per cent $(n=3)$ were the daughter of the head, 1.2 per cent $(n=3)$ were the wife of the head, 2.4 per cent $(n=6)$ were "boarders and lodgers" and 1.6 per cent $(n=4)$ were other family relations of the head (father, mother, brother-in-law, sister). Our results suggest that, in 1901, home ownership was not a prerequisite for establishing a home-office, since even a physician boarding or lodging in a household could presumably take on extra rooms to establish a home-based practice.

As the examples provided among woman doctors suggest, home-office physicians lived in a range of family and household structures. The majority of these physicians were married (80.7 per cent, $\mathrm{n}=197)$ at the time of the 1901 census, while a smaller percentage were unmarried ( 15.6 per cent, $n=38$ ) or were widowed ( 3.7 per cent, $n=9$ ). Home-office physician households were classified according to a truncated Statistics Canada household classification scheme (truncated because common-law unions were not recognized in 1901). Within this scheme there are nine possible household types: husband/wife (Type 1), husband/wife and additional persons (Type 2), husband/wife/never married children (Type 3), husband/wife/never married children and additional persons (Type 4), one parent/ never married children (Type 5), ${ }^{38}$ one parent/never married children and additional persons (Type 6), multiple family (Type 7), lone individual (Type 8), and a non-family grouping (Type 9). Figure 16 depicts the distribution of these household types in Toronto physician home-office households and in Canadian 1901 homes more generally (based on an analysis of the Canadian Family Project's 5 per cent sample of the 1901 population of Canada). ${ }^{39}$ Relative to the average Canadian household, Toronto physicians and their families were significantly more likely to be living in households with "additional

\footnotetext{
${ }^{38}$ In 1901, the majority of "one parent" families were created through the death of a spouse and not divorce or separation.

${ }^{39}$ See Eric W Sager, Douglas K Thompson, and Marc Trottier, The national sample of the 1901 Census
}

of Canada: user's guide, revised edition, http://web. uvic.ca/hrd/cfp/data/1901\%20Census\%20User\% 20Guide.pdf 
The Architecture of Home-offices for Physicians in Toronto, 1885-1930

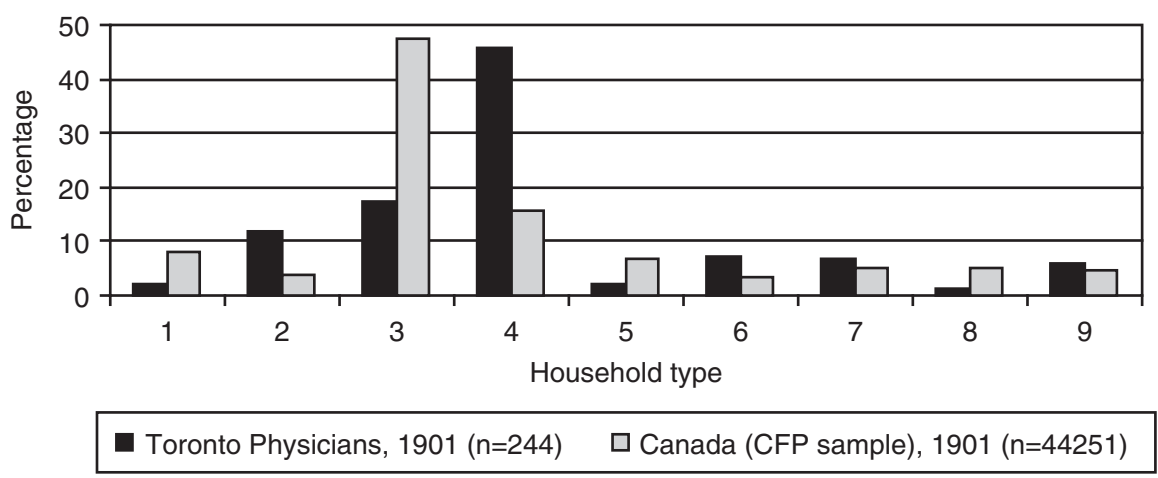

Figure 16: Distribution of these household types in Toronto physician home-office households and in Canadian homes more generally in 1901, based on an analysis of the Canadian Family Project's 5 per cent sample of the 1901 population of Canada.

persons" (household types 2, 4, and 6). The nuclear family predominates, both for Toronto physicians as well as average 1901 Canadian households. But the important difference between the two is the overwhelming presence of "additional persons" living alongside physicians' families. In the majority of 1901 Canadian households, 47 per cent of households, the nuclear family lived alone-mother, father, and unmarried offspring. For the majority of Toronto home-office physician households, however, 46 per cent were nuclear families living together with an assortment of "additional persons". Though proportionately less common, the same tendency was true among husband/wife households (where Type 2 households with additional persons are more common among Toronto physicians) and single parent/offspring households (where Type 6 households with additional persons are again more common among the physicians). While 1901 households in general were much more open to extra-family persons relative to Canadian households today (which tend to be restricted to family members), ${ }^{40}$ physicians' families stand out in this regard.

A more detailed examination of the precise identities of these additional persons reveals a predominance of non-related persons. Among Type 2 (husband/wife and additional persons) physician households, for example, the majority of additional persons (77.2 per cent, $\mathrm{n}=44$ ) were domestic workers (including maids/servants/nurse/page); of those remaining, 14.0 per cent $(n=8)$ were relatives, and 5.3 per cent $(n=3)$ were boarder/lodgers. Two persons (3.5 per cent) had "other" or ill-defined relationships to the household head. The same general pattern is observed in Type 4 (nuclear family with additional persons) physician households, where, once again, the majority of additional persons (66.0 per cent, $\mathrm{n}=138$ ) were domestic workers; of those remaining, 22.0 per cent

\footnotetext{
${ }^{40}$ See Stacie Burke, 'Transitions in household and family structure: Canada in 1901 and 1991', in Eric W Sager and Peter Baskerville (eds), Household
}

counts: Canadian households and families in 1901, University of Toronto Press, 2007. 
$(n=46)$ were relatives, 9.1 per cent $(n=19)$ were boarder/lodgers and 2.9 per cent $(n=6)$ were "other" persons. While domestics continue to be important contributors to the Type 6 (single-parents and children with additional persons) physician households ( 35.3 per cent, $n=12)$, some 32.4 per cent $(n=11)$ were boarder/lodgers, 20.6 per cent $(n=7)$ were relatives, and 11.8 per cent $(n=4)$ were "other" persons. The ubiquity of live-in domestics suggests a high level of wealth among these physicians, especially since a number of households had more than one. In the census, most domestics working in physician households reported earnings of between $\$ 100$ and $\$ 150$ per year.

The Peters-Primrose duplex on College Street provides two typical examples of the Type 4 household. According to the 1901 census, the Primrose household consisted of 39and 37-year-old Dr and Mrs Primrose, ${ }^{41}$ their three children (ages ten, eight, and six) and three Canadian-born women servants (ages thirty, twenty-three, and twenty-one; who earned between $\$ 120$ and $\$ 144$ a year). Their immediate neighbours, the Peters family, included the parents, a baby girl, and two domestics. While the employees are vaguely described in the census as "employed as a servant", it is possible that their duties-like the responsibilities of some doctors' wives-extended beyond typical domestic responsibilities to assisting with the upkeep and functioning of the medical office. ${ }^{42}$ In the sources examined for this study, it is impossible to know precisely the involvement of servants in the practice of medicine. Perhaps household financial records, servants' diaries, or physicians' autobiographies will shed light on this question in the future.

All of our house plans illustrate the typical design strategies used by wealthy families to maximize separation from live-in domestics, including back entrances and separate kitchen staircases leading up to a servant-bedroom zone and down to laundry and other service rooms in the basement. House-office architects had the added challenge of opening the home to patients, while also trying to maintain privacy from live-in "additional persons". There is no architectural evidence, however, that having patients in the house meant a greater need to seclude servants from the family. In the Peters-Primrose duplex, for example, which showed the highest degree of planned spatial overlap between patient and family spaces, servant bedrooms are located on the uppermost floor, not far from two spacious nurseries and a family bedroom. Still, the servant bedrooms occupied only a corner and could presumably be closed off.

\section{High-Rise Medical Buildings}

The golden age of Toronto's house-offices ends about 1930, with the construction of non-residential medical offices like the 1929 Toronto Medical Arts Building (Figure 17),

\footnotetext{
${ }^{41}$ Primrose's first wife (enumerated in the 1901 census), Mrs Clara Ewart Primrose, died in 1919. Elizabeth Britton Primrose, his second wife, died two months after her husband in 1944. See Globe and Mail, 13 Apr. 1944, Alexander Primrose, Scrapbook A73-0026/368(86), University of Toronto Archives.

${ }^{42}$ Family member participation in the house-office is also of interest since a survey of physicians
}

practising in Ontario in the early 1960s found that a number of male doctors who had been in practice since the 1940 s or 1950 s routinely depended on their wives to be present at physical (gynaecological) examinations of women patients and to provide occasional secretarial and nursing assistance. See Kenneth Clute, The general practitioner: a study of medical education and practice in Ontario and Nova Scotia, University of Toronto Press, 1963, pp. 65-6. 


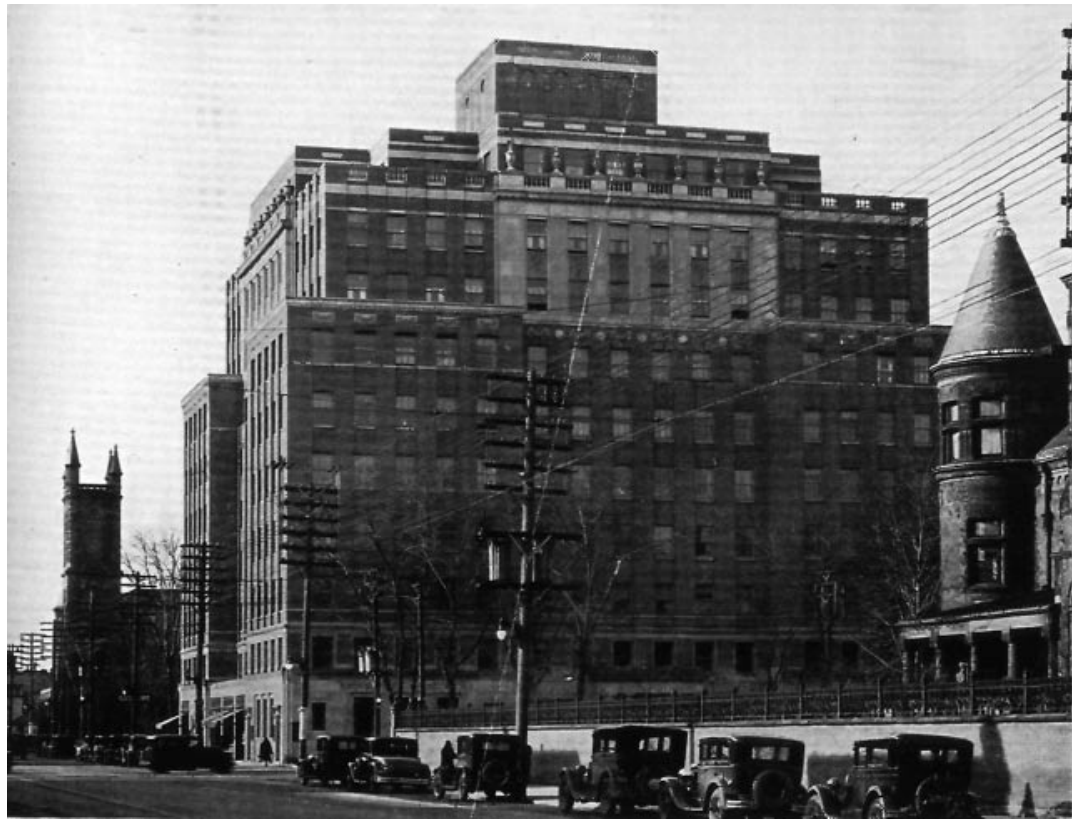

Figure 17: Toronto Medical Arts Building. Journal of the Royal Architectural Institute of Canada, Feb. 1930, 7: 55.

built by the architects Marani, Lawson \& Paisley at the corner of Bloor and St George Streets in the centre of the house-office cluster. The doctor's office now became part of a modern, multi-storeyed office tower, not a house. ${ }^{43}$ We speculate that trappings such as antiques, books, servants, and wives were no longer essential or appropriate to convince patients of a doctor's competence; by 1930 patients came to expect, instead, state-of-the-art non-medical technologies and services such as the elevator, telephone, parking, coffee shop, bank, and adjacent gas station boasted by the developers of the Medical Arts Building. ${ }^{44}$ Location remained important socially; a journal article emphasizes that the Toronto tower was "located at the north-west corner of Bloor and St. George Streets in the heart of the city's exclusive up-town section". ${ }^{45}$

\footnotetext{
${ }^{43}$ Medical journals after the First World War featured many articles on how to arrange ideal offices. See, for example, Charles M Harpster, 'Some practical offices for the surgeon with illustrations', The Ohio State Medical Journal, Aug. 1919, 15: 478-82; Faber Birren, 'The psychological value of color', Modern Hospital, Dec. 1928, 31: 85-8. The subject seems to have been particularly popular in the journal Medical Economics (ME). See 'Can an office express its owner's individuality', $M E$, Feb. 1929, 6 (5): 31-2, 34-5, 37; W F McCulloch, 'Laying out the office', $M E$, April 1929, 6 (7): 41-7; Milton Tucker, 'Making the most of a suburban office', $M E$, June 1929, 6 (9): 20-1,
}

57-61; Robert S Staples, 'Re-decorating in modern style', $M E$, Jan. 1931, 8 (4): 14-16, 113; 'A suggested plan for the medical suite', $M E$, Mar. 1928,5(6): 12-13, 40-1; Frederick C Smith, 'Our clinic — and how it operates', $M E$, Sept. 1928, 5 (12): 15-17, 71.

${ }^{44}$ On non-medical technologies in the hospital, see Joel Howell, Technology in the hospital: transforming patient care in the early twentieth century, Baltimore, Johns Hopkins University Press, 1995, pp, 30-68.

45 'The Medical Arts Building, Toronto', Journal of the Royal Architectural Institute of Canada, Feb. 1930, 7: 59. 


\section{Annmarie Adams and Stacie Burke}

The increasingly scientific approach among physicians meant that their offices needed to accommodate even more specialized medical equipment, apparatus that might not have fitted or suited the domestic context. ${ }^{46}$ Shumsky, Bohland, and Knox cite large pieces of equipment, such as "sterilizers, X-ray units, diathermy machines or refracting outfits"; collections of smaller equipment which would need to be stored and on-hand, such as "laboratory glassware, microscopes, centrifuges, vibrators, baumanometers, sphygmomanometers, syringes, needles, cotton, gauze, bandages, plaster and gloves"; as well as myriad office and examination room furniture. ${ }^{47}$ Despite the move of physicians' offices out of the family home, doctors continued to surround themselves in domestic imagery, which retained an important place even in this new professional context. Architects accommodated new medical technologies in medical high-rises, but softened its impact through home-like touches. The Medical Arts Building in Toronto, for example, included a twelve-bed hospital which was made to look as homey as possible: "Patients themselves enjoy the atmosphere of the hospital, which as we have said before, has been made as uninstitutional as possible and yet as scientific as illness demands", claimed a journalist writing for Canadian Hospital. ${ }^{48}$ It is precisely the tension between domesticity and science which Shumsky, Bohland, and Knox argue transformed the practice venue since "once doctors had perceived 'scientific skill' as a 'commodity' to be bought and sold, the home-office conjunction could no long continue to exist". 49

Some of the same successful doctors who commissioned house-offices were key players in the development of clinical high-rises. In Toronto, 200 doctors participated in the venture to establish the Medical Arts Building; Dr Primrose was the president of the development. Each physician in the organization was part owner of the building and had office space allocated therein. ${ }^{50}$ By 1919 Primrose (soon to be the new dean of the Faculty of Medicine at the University of Toronto) had left the downtown duplex he had inhabited next to Peters, moving his home to 50 Forest Hill Road, near the intersection of St Clair Avenue and Avenue Road, decidedly north of the central core where he had once lived. Forest Hill would become one of Toronto's most prestigious neighbourhoods. This spatial dynamic of downtown office and outlying residence was a new phenomenon observed by Shumsky, Bohland, and Knox for physicians in San Francisco during the transitions taking place in medical practice between 1881 and $1941 .^{51}$ And just when the doctor's home left downtown for good, other non-medical typological hybrids appeared too. Modern urban office buildings in the 1920s began to include medical

\footnotetext{
${ }^{46}$ Olson pointed out the need for specialized equipment to us, citing the example of surgery. Procedures such as bone-setting and lancing boils could be done in the doctor's office, but the expansion of surgery to a range of more complex interventions required more specialized equipment; personal correspondence, 23 Feb. 2005. The house-office still thrives today in psychiatry and psychotherapy, where there is no need for specialized equipment or technical platforms.

${ }^{47}$ Shumsky, Bohland, and Knox, op. cit., note 9 above, pp. 1055-6.
}

\footnotetext{
48 'A miniature hospital is a feature of the Medical Arts Building, Toronto', Canadian Hospital, June 1930, 7: 22.

${ }^{49}$ Shumsky, Bohland, and Knox, op. cit., note 9 above, p.1057.

${ }^{50}$ Globe, 18 May [1928], Alexander Primrose, Scrapbook A73-0026/368(86), University of Toronto Archives.

${ }^{51}$ Shumsky, Bohland, and Knox, op. cit., note 9 above.
} 


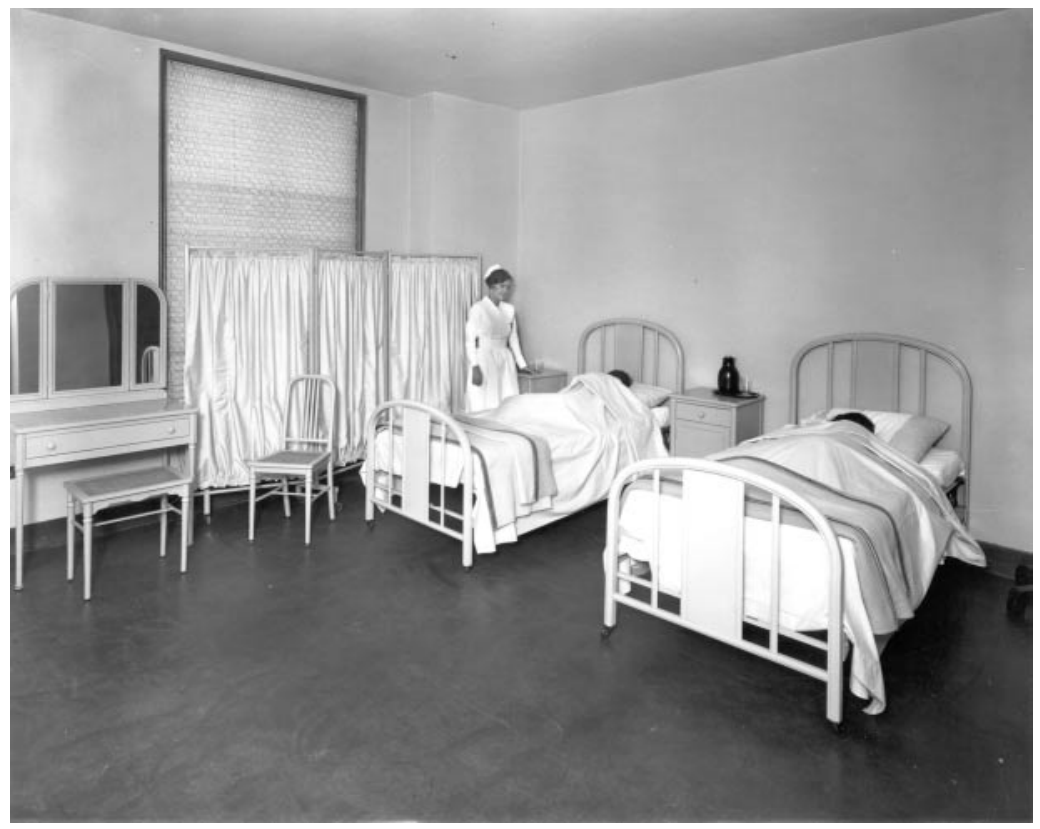

Figure 18: Bell Telephone Company, Beaver Hall Building, Montreal, 1928-29, including medical facilities. \#9756C. Courtesy Bell Canada Historical Collection.

offices. Barott and Blackader's Bell Telephone Company, Beaver Hall Building, Montreal, of 1928-29 (Figure 18), for example, boasted a whole floor of medical facilities.

The move from the intimate house-office to the relatively anonymous, but still exclusive, office tower is an important subject for future research. Shumsky, Bohland, and Knox noted that, in San Francisco, "the majority [of physicians] had ceased to work at home by 1911 , and the separation of home and office was nearly universal by 1941 ". 52 The factors they cite to account for this move include: the increase in scale of physicians' practices to include receptionists, nurses, secretaries, and book-keepers; the need to strengthen links between general practitioners and specialists for the most efficient medical care of patients; the rise in physicians' income (which made the split possible); improvements to transportation and communication infrastructure; and the change in doctors' own perceptions of their practices, since many "came to see themselves more as scientists than as family friends, [and] it became more appropriate to treat patients in laboratory-like rather than home-like settings". 53

Physicians drew their insights for group-based medical practice from several models. In Rochester, Minnesota, the Mayo Clinic, a family-based collaboration which began in the 1880 s, grew into a dynamic institution with seventeen doctors, eleven clinical assistants, and its own building in $1914 .{ }^{54}$ The Mayo Clinic became a primary model for cooperative

${ }^{52}$ Ibid., p. 1052 .
${ }^{53}$ Ibid.
${ }^{54}$ See Starr, op. cit., note 10 above, pp. $210-11$. 
practice among physicians, attracting national and international attention. ${ }^{55}$ Cooperative practice was also embodied in the staffing of general hospitals. Hospital employment, however, was a trade-off to the independence which physicians enjoyed in their own practice. It is important to re-state that the doctors involved in the Medical Arts Building bought into the cooperative practice which emerged. According to Madison, hospitalbased employment might have attracted specialists because of the presence of expensive but necessary medical equipment, but, by banding together, enterprising independent physicians could secure the same equipment. Further, Madison argues, "for a more technologically intensive style of practice to spread beyond the hospital into the private office, the physician had to adjust his outlook and assume the unfamiliar role of proprietor of a commercial enterprise". ${ }^{56}$ The timing of the Medical Arts Building may also be tied, to some extent, to another example of group practice outlined by Madison, namely, the "highly organized medical work in the base hospitals" experienced among physicians working overseas during the First World War. ${ }^{57}$ Was it merely coincidental that the president of the Medical Arts Building organizing committee, Dr Primrose, had joined the military effort, lending his surgical expertise to base hospitals in Europe between 1915 and 1917 ?

The free dispensaries and medical high-rises differed in two significant ways: clientele and design specificity. Still, the free dispensaries (see Figures 13-14) represented another model for physicians who moved their practice to non-residential medical towers. They may have provided physicians with an early cooperative model for more centralized dayto-day medical care in non-residential buildings. According to Might's Directory, Dr Machell was one of eleven attending physicians who worked at the charitable Toronto Dispensary (133 Simcoe Street) in 1901. The plans for his 1886 house-office reveal that he was also seeing patients at home. Doctors who worked at the free dispensaries thus participated in a collective health care delivery model, requiring an approach different from the entrepreneurship behind the isolated home-office, and more closely aligned to a model of cooperation in which physicians shared material and human resources.

\section{The Interconnectedness of Architects and Physicians}

In the early years of our study, the custom of visiting patients in their own homes persisted among some physicians, particularly general practitioners. This probably distinguished them from the home-office preference of rising specialists represented in our case studies. This sub-group of physicians may have sought out the professional services of architects for several reasons. Firstly, they may have needed more specialized spaces than general practitioners, and turned to architects to renovate an existing home (for example, Dr Eaton) or to design purpose-built space (such as the duplex for surgeons Peters and Primrose). Secondly, medical specialists likely had more money for formal architectural remodelling and design. Thirdly, the general practitioners may have organized their home-based practices more modestly than the specialists and, as a result, divided their

\footnotetext{
${ }^{55}$ Madison, op. cit., note 27 above, p. 477.

${ }^{56}$ Ibid., p. 459.
}

${ }^{57}$ Ibid., p. 483. 
The Architecture of Home-offices for Physicians in Toronto, 1885-1930

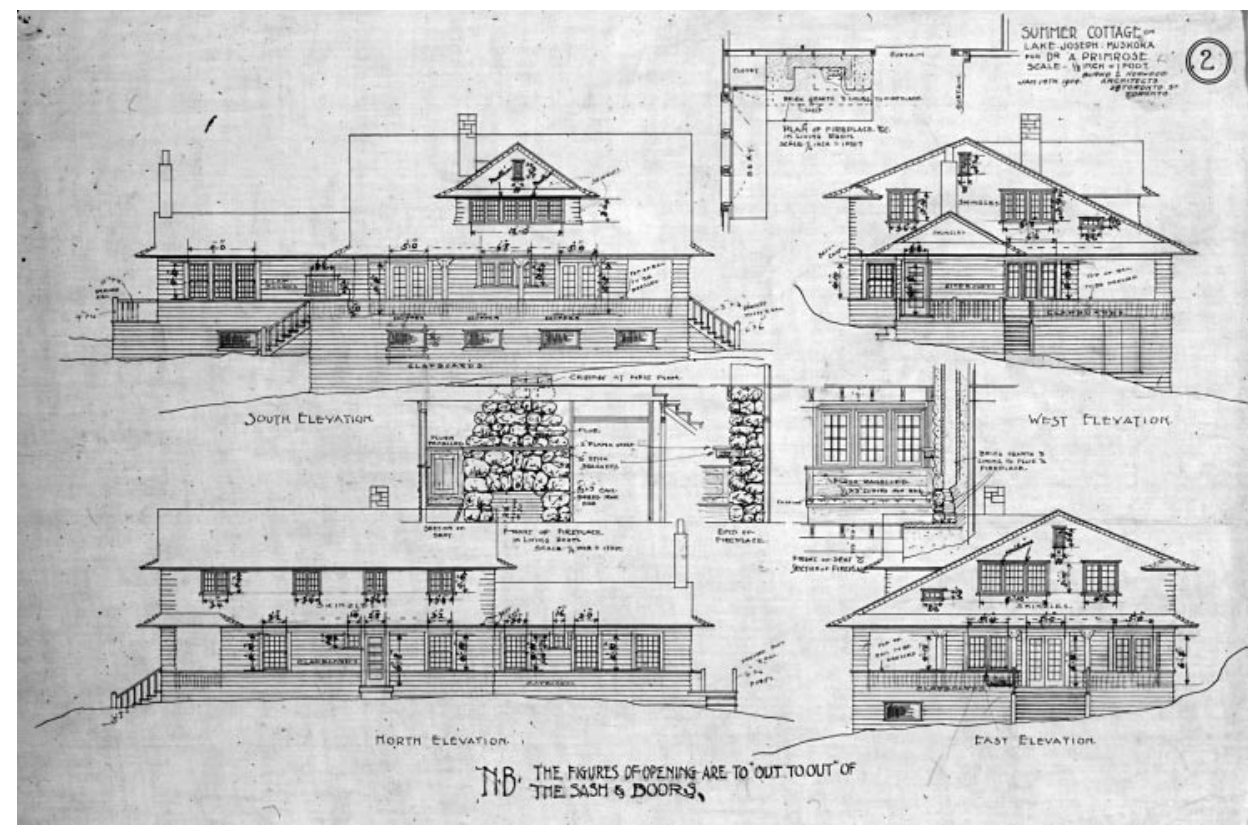

Figure 19: Detail of cottage for Dr Alexander Primrose, Muskoka, Ontario. Archives of Ontario, C 11-1095, (889) 10.

homes along less rigid lines. This might mean a patient waiting-room by day became a family drawing-room at night.

Whatever the reason that physicians sought out architects, specialist doctors, business/ academic leaders and a handful of architects formed an elite group. In this wealthy and welleducated circle, word-of-mouth could go far in furthering an architect's career. D B Dick, who designed home-offices for Machell (1886), Thorburn (1891), and Peters-Primrose (1898), was commissioned for a number of projects at the University of Toronto, including a post-fire restoration of University College in $1890 .{ }^{58}$ The network of Toronto architects and doctors also played out beyond the city's limits. Burke \& Horwood designed for the idyllic cottage country of Muskoka, roughly 160 kilometres north of Toronto. Torontonians fled here for recreation, but also to use the area's tuberculosis sanatoria. Muskoka, like Saranac Lake in New York State, came to represent health and vigour. ${ }^{59}$

The relationships between physicians and architects in turn-of-the-century Toronto extended beyond the design of home-offices. The Primrose cottage (Figure 19) was located in Muskoka and the design included no space whatsoever for his medical practice, suggesting that Dr Primrose chose Burke \& Horwood for reasons other than their health

\footnotetext{
${ }^{58}$ See http://www.newsandevents.utoronto.ca/ bios/02/history6.htm.

${ }^{59}$ On architecture for tuberculosis at Muskoka, see Annmarie Adams and Stacie Burke, " Not a shack
}

in the woods": architecture for tuberculosis in Muskoka and Toronto', Can.Bull.med.Hist., 2006, 23 (2): 429-55. 
care expertise. The same architects also designed a Toronto home for William Gage, publisher, philanthropist, and founding member of the National Sanitarium Association, as well as a number of the Muskoka and Toronto sanatorium buildings. Burke and his associates struck complex connections with the medical community, the university, and philanthropists who supported health care and education.

Not surprisingly, complex familial connections linked some of the doctors whose architect-designed home-office plans or renovations we have located. For example, Herbert Hamilton, whose home-office was designed by Burke \& Horwood, was the nephew of J E Graham, whose home-office was designed by Langley \& Burke. Dr Thorburn's son, Dr James David Thorburn, also ran a practice in Toronto. Both the younger Thorburn and Dr Peters, of the College Street duplex, married daughters of Sir William Ralph Meredith, who served as chief justice of Ontario and was chancellor of the University of Toronto from 1900 to 1923 . As these examples show, the relationships between doctors, business/university leaders, and architects cluster and overlap, just like the house-offices they built together. And the social and familial links are as complex as the pocket doors, Palladian windows and double entry sequences carefully designed to separate patients, families, and servants.

\section{Epilogue}

This paper is a first step in a continuing exploration of the relationship of design and medical practice in early-twentieth-century Canada. Further research will sharpen our understanding of the disappearance of the home-office as an everyday work environment for doctors. Its survival in architectural drawings, coupled with biographical information and data from the national census, exposes the inner life of this important building typology. Our study illustrates a remarkable density of clustering in an area better known for its hospitals than its homes, and illustrates complex social and physical networks among architects, doctors, university administrators, and philanthropists. Finally, it underlines the importance of studying place as a historical source in the history of medicine. 